\title{
EARLY WEICHSELIAN BIOSTRATIGRAPHY AND VEGETATIONAL DE- VELOPMENT AT HORONKYLÄ, POHJANMAA, WESTERN FINLAND
}

\author{
TUULIKKI GRÖNLUND and LIISA IKONEN
}

TUULIKKI GRÖNLUND and LIISA IKONEN 1996. Early Weichselian biostratigraphy and vegetational development at Horonkylä, Pohjanmaa, Western Finland. Bull. Geol. Soc. Finland 68, Part 1, 61-84.

A diatomite layer covered by two till units was found at Horonkylä, Teuva, Pohjanmaa, western Finland. The diatomite layer represents infill sediment in a freshwater lake formed within a dead ice hollow in a glaciofluvial formation interpreted as an esker. The deposition of diatomite was terminated by advancing ice, which deformed underlying sediments and deposited the first till unit (Horonkylä till) in the sequence. During the ice retreat a silty clay layer was formed in the basin close to the ice front. A renewed glacal advance deposited the upper till unit (Horonpää till).

According to the diatom flora the diatomite was deposited in a shallow, freshwater basin in which at least slight water level changes occurred during the sedimentation. On the basis of biostratigraphy the diatomite was deposited during Brörup interstadial. The pollen flora indicates a forest succession from an initial birch forest to a denser pine forest. Dating of the diatomite layer is based exclusively on the biostratigraphy. The silty clay layer was deposited in a basin close to the ice front and the initial stages of sedimentation were interrupted by a short pulse of secondary Eemian material.

Key words: pollen analysis, diatom flora, lithostratigraphy, Brörup interstadial, Horonkylä, Teuva, Pohjanmaa, Finland.

Tuulikki Grönlund and Liisa Ikonen, Geological Survey of Finland, FIN02150 Espoo, Finland

\section{INTRODUCTION}

Several till-covered old eskers are known from Pohjanmaa, western Finland (Iisalo et al. 1974, Niemelä \& Tynni 1975, 1979, Niemelä 1978, 1979). Some of these eskers are sites of organic deposits interpreted as interglacial or interstadial (Niemelä \& Tynni 1979, Donner 1988, Gibbard et al. 1989, Eriksson \& Kujansuu 1994). Often covered with sand, the organic deposits rest on esker sediments in kettle-like depressions, where they were protected from erosion by the last glaciation.

The preservation of the old till-covered eskers is partly due to the diversity of the local topography and the large differences in relative heights 
(Niemelä 1979) and partly to the passivity of the continental ice sheet during the last deglaciation, which contributed to the low degree of glacial erosion and hence to the preservation of old forms and formations (Punkari 1979).

In the northwestern part of Teuva one of the eskers runs through Horonkylä from SSE to NNW as a gently sloping ridge, $200-400 \mathrm{~m}$ wide (Figs 1 and 2), that at Horonpää has developed into a deltaic expansion (Kurkinen 1973). The discovery of a diatomite layer almost two metres thick and of a pure white colour, in the Horonpää formation led to reinvestigation of the formation in summer 1992. A new section was cut in the wall of a

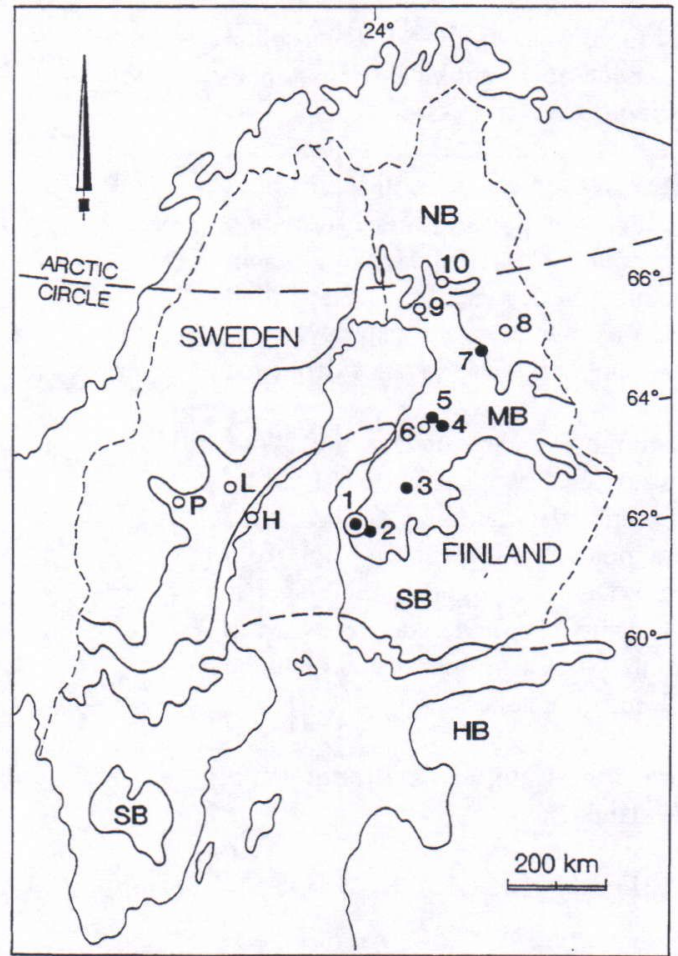

Figure 1. The study site Horonpää (1) and the interstadial sites referred in the text: 2. Harrinkangas, 3. Vimpeli, 4. Marjamurto, 5. Oulainen, 6. Mertuanoja, 7. Ruottisenharju, 8. Kostonniska, 9. Kauvonkangas, 10. Permantokoski, H. Härnösand, L. Långsele, P. Pilgrimstad. The vegetation zones in northwestern Europe: HB Hemiboreal, SB Southernboreal, MB Middleboreal, NB Northernboreal (according to Ahti et al. 1968). Interstadial sites with birch (O) and those with pine dominance $(\bullet)$.

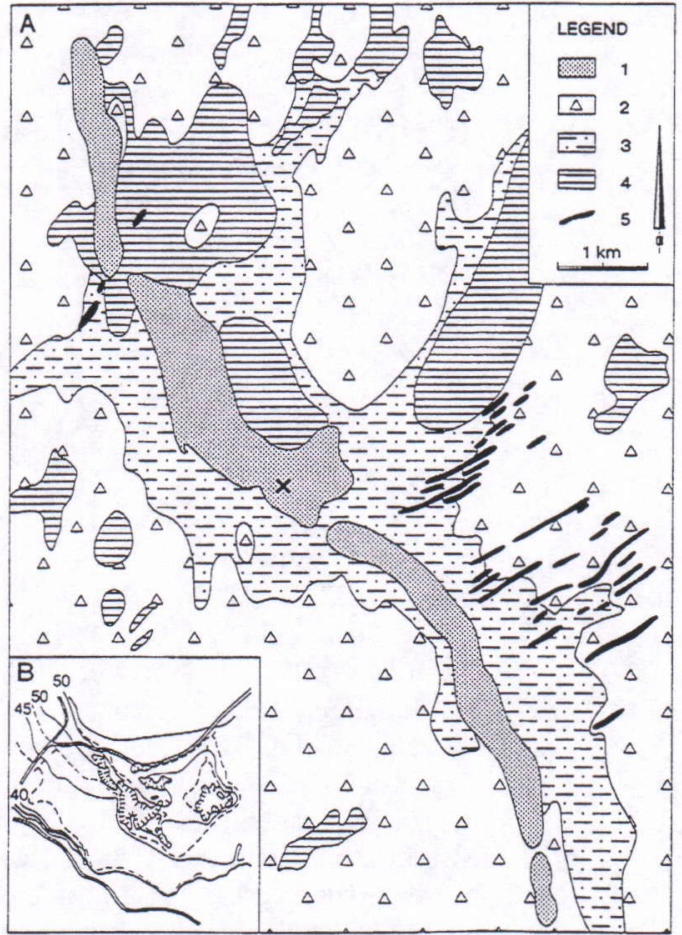

Figure 2. A Horonkyä esker and surrounding Quaternary deposits and bedrock surrounded (constructed by Kujansuu). Symbols: 1. esker, 2. till and bedrock outcrops, 3. clay and silt, 4. peat, 5. De Geer moraines. The sampling site is marked with X. B The Horonpää gravel pit. Contour lines at intervals of 5 and $10 \mathrm{~m}$ (sketched from basic map (1987)).

landscaped gravel pit to establish the stratigraphic position of the diatomite.

Diatomite is a light coloured, soft and porous sediment deposited in water. It is mainly composed of the microscopically tiny silica frustules of diatoms. The hardness of the frustules, which are of amorphic silica $\left(\mathrm{SiO}_{2} \times \mathrm{H}_{2} \mathrm{O}_{2}\right)$, is $41 / 2-61 / 2$ on Mohs' scale. Their thickness varies depending on the species. Diatomite deposits commonly contain clay and silt. Commercial diatomite generally consists of about $90 \%$ silica, the remainder of the material being chiefly alumina and alkalies from the included clay.

Numerous diatomite deposits have been discovered in Finland (e.g. Nieminen 1976, Grönlund $1986,1989)$. They are quite small in size. All these 
diatomites are young occurrences deposited on the bottom of freshwater basins during the Holocene. Late Tertiary reworked diatomite material from Salla (Hirvas et al. 1977, Tynni 1982), an Eemian occurrence from Savukoski (Ilvonen 1973) and probably an interstadial one from Oulainen (Forsström 1982, 1988) have also been described. Redeposited interglacial or interstadial diatomite lenses are also found in Haapajärvi (Aario 1966).

The subject of this paper is the biostratigraphy of the Horonpää formation. The sequences were sampled by R. Kujansuu and K. Nenonen on two occasions, in 1992 and 1995.

\section{SITE DESCRIPTION}

The Horonpää site is located at $62^{\circ} 36^{\prime} \mathrm{N}, 21^{\circ} 36^{\prime} \mathrm{E}$ (map sheet 1241 12, $\mathrm{x}=6944.84, \mathrm{y}=1530.91, \mathrm{z}=51$ $\mathrm{m}$ a.s.1.) $1.8 \mathrm{~km}$ northeast of the village of Horonkylä, in the southern Pohjanmaa (Fig. 2).

The Horonkylä area is characterized by large, gently sloping rocky elevations with summits at 70-100 $\mathrm{m}$ a.s.l. The absolute elevations of the valleys, which are covered with postglacial sediments and are partly paludified, are less than $50 \mathrm{~m}$ : the Närpiönjoki river valley, for instance, lies at 15-20 $\mathrm{m}$ a.s.l. and the Itäjoki river valley at about $40-50$ $\mathrm{m}$ a.s.l. The highest summits of the Horonkylä esker rise almost $20 \mathrm{~m}$ above the valley of the Itäjoki in the southwest and almost $15 \mathrm{~m}$ above the level of Tresket, a drained lake east of the esker.

Lodgement till of variable thickness and composed of two units, at least in the Horonpää section, follows the topography of the bedrock. In southern Pohjanmaa, the lower of two superimposed till units was deposited by continental ice flowing from the northwest and the upper unit by ice from the north (Hirvas \& Nenonen 1987).

In the Itäjoki river valley, east of Horonkylä esker, there are a number of small ice-marginal formations interpreted as De Geer moraines. The orientation of their longitudinal axes, which is from southwest to northeast on average, shows that the continental ice sheet withdrew roughly northwestwards.

The lowest parts of the terrain are covered with late-glacial and postglacial lacustrine and marine clay and silt deposits. Low-lying waterlogged till, silt and clay areas are often paludified.

The study site is located at the boundary line between the middle and southern boreal vegetation zones. Most of the sites referred to lie in the middle boreal vegetation zone.

\section{LITHOSTRATIGRAPHY}

The pollen and diatom analysis were studied from three different sections (A, B and C), the positions of which are shown in Figure 3. Since the sediments resting on the diatomite layer had been removed a shallow ditch was excavated perpendicular to the wall of the gravel pit, where the sediments above the diatomite layer were still discernible (see Figs. 3 and 4). The position of the diatomite layer, below two till units was confirmed with certainty. The lithostratigraphy of the Horonpää formation has been described previously by Nenonen (see Fig. 18, 1995).

Eight main lithostratigraphical units can be distinguished in the section B (Fig. 3):

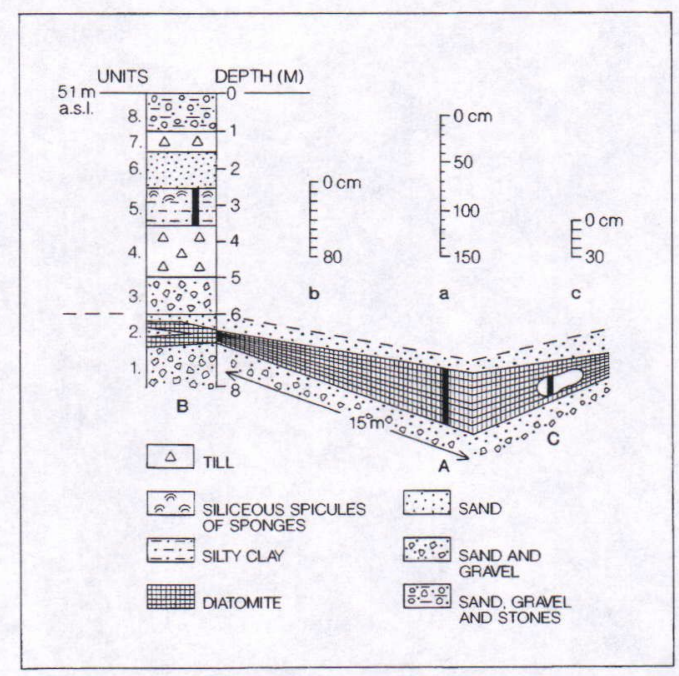

Figure 3. Sections (A, B and C) at Horonpää site showing positions of samples for pollen and diatom analysis from profiles $a, b$, and c. 1-8 lithostratigraphical units. The dashed line marks the surface of the gravel pit bottom at the time of sampling. The section B sketched after Fig. 18 in Nenonen 1995. 
Unit 1. Sand and gravel of glaciofluvial origin.

Unit 2. Diatomite layer of varying thickness within sand. In the section studied (A) the thickness of the layer is $155 \mathrm{~cm}$. The diatomite layer is partly deformed. This layer, which is locally underlain by primary glaciofluvial sand and gravel (Figs. 3 and 4), shows folds, overthrust structures, faults, stones and sand wedges. In places the diatomite is mixed with sand and fines-rich till. According to its chemical composition, the diatomite is of quite good quality, its $\mathrm{SiO}_{2}$ content being $90.4 \%$ and losson-ignition 1.9-3.4\% (Nenonen 1995).

Unit 3. Stratified sand with folded and faulted structures.

Unit 4. Lodgment till rich in fines (Horonkylä till) and dark grey in colour. According to fabric analysis the till was deposited by ice flowing NNW. The till has a sharp erosional contact with the underlying sand.
Unit 5. Silty clay layer, $80 \mathrm{~cm}$ thick, in the upper part of which siliceous sponge spicules were found. Material as rich in siliceous spicules of sponges as that found at the Horonpää site (Fig. 6) is rare in Finland.

Unit 6. The lower part of the unit consists of structureless, massive coarse sand and the upper part of horizontally laminated fine sand. The sand layers represent an ancient littoral deposit.

Unit 7. Unconsolidated lodgment till rich in fines and clayey and bluish-grey in colour (Horonpää till). According to fabric analysis the till was deposited by ice flowing NNW. The till has a sharp erosional contact with the underlying sand.

Unit 8. Sand, gravel and stones representing littoral deposition.

The sedimentary sequence commenced with subglacial (glaciofluvial) sedimentation of sand and gravel (Unit 1), which formed the Horonpää esker. Diatomite (Unit 2) was deposited in a lake

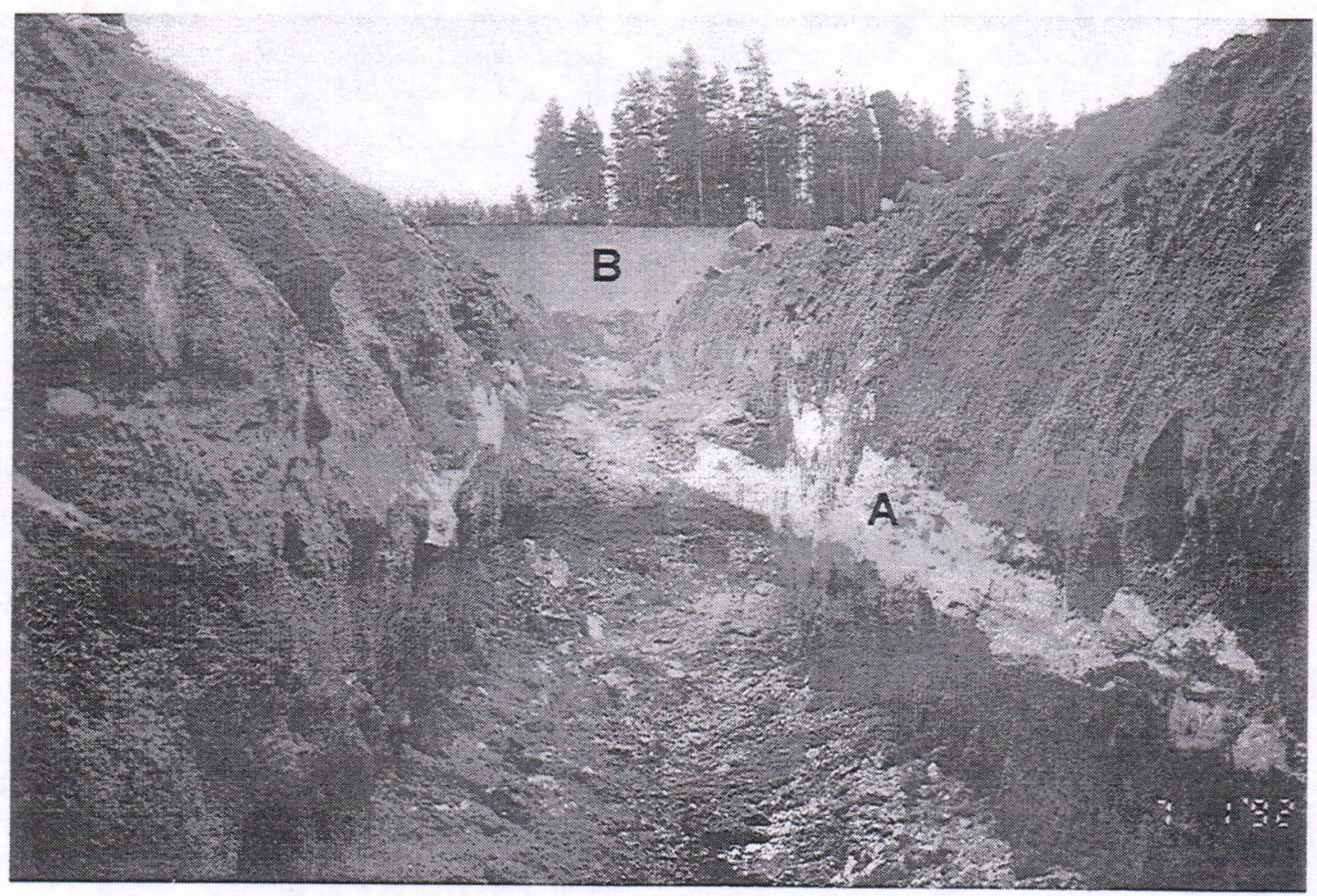

Figure 4. Horonpää gravel pit. Interstadial diatomite layer (A) and the strata (landscaped) overlying it (B) (cf. Fig. 3). Photograph: K. Nenonen. 
situated in a dead ice hollow formed in the esker. The structures in the diatomite imply that the material later underwent deformation by glacio-tectonic processes but the stratigraphical position of the layer below two till units obviously remained unchanged (Kujansuu 1996, oral comm.). According to Nenonen (1995) the diatomite was possibly trasported by glacial flow before being deposited at its present site in much the same way as happened in the till-covered gyttja deposit at Norinkylä, Teuva (Donner 1988).

The diatomite was covered and protected by a sand layer (Unit 3). During the oscillation of the Lower and Middle Weichselian ice sheet two till layers were deposited, first the Horonkylä till (Unit 4) and later Horonpää till (Unit 7) (Nenonen 1995). Between these two glaciations an ice-free period existed during which fine-grained sediments such as silt and clay were transported by melt waters and deposited first (Unit 5), followed later by more sandy material (Unit 6).

A separate diatomite block with varying amounts of coarse detritus gyttja, which was also studied is preserved diagonally within the diatomite layer. The block is situated in the wall of the trench, which was excavated nearly perpendicular to the first trench (Section C in Fig. 3). The distance between the sections $\mathrm{A}$ and $\mathrm{C}$ is approximately five metres. The variation in the abundance of coarse detritus gyttja shows that the block was not deposited in the same place as the diatomite layer surrounding it. The sequence was probably laid down nearer the shore of the same water body in which the diatomite was deposited and transported by glacio-tectonic disturbances to its present position. The structure of the block, however, shows that the block survived the deformation unaffected.

\section{METHODS}

The samples for pollen and diatom analyses were taken from the diatomite (Unit 2) and the silty clay (Unit 5), and from the separate diatomite block. The diatomite layer at section A was only slightly deformed.
The pollen analysis was made on the diatomite at intervals of 5-20 cm, but only from 10 samples. The silty clay was analysed at intervals of $10 \mathrm{~cm}$. Ten pollen samples at intervals of $2-5 \mathrm{~cm}$ were analysed from a supplementary sequence obtained from the diatomite block. A sample taken from wood twigs found in the same section was also analysed. The samples for pollen analysis were treated with hydrogen fluoride (cold method, Müller 1953) and then boiled in $10 \% \mathrm{KOH}$.

The diatom analysis was performed at intervals of $10 \mathrm{~cm}$ on diatomite and silty clay layers. Ten samples were also analysed from the diatomite block. For the diatom analysis, organic matter was removed by bleaching in $\mathrm{H}_{2} \mathrm{O}_{2}$ for $24 \mathrm{~h}$ at $50^{\circ}$ followed by several washings. The mineral matter was removed by repeated suspension and decantation.

Loss-on-ignition was obtained for units 2 and 5 , and the diatomite block. The loss-on-ignition values are given as percentages of dry weight (Figs 7-9).

The material siliceous spicules of sponges was identified using a number of analytical methods. The X-ray diffraction power method showed that it was amorphous; simultaneous thermogravimetric and differential thermoanalytical techniques confirmed that it was composed of opal, and investigation under a polarizing microscope ensured that it was of organic origin with the composition of opal (analysed by K. Lindqvist).

\section{BIOSTRATIGRAPHY}

\section{Pollen record}

The pollen spectra were determined using one or two slides for diatomite, but up to six slides for samples of silty clay with a lower pollen frequency. The sums from which the percentages of the pollen and spore types were calculated are indicated in the diagrams (Figs 7-9).

\section{Diatomite layer (Unit 2, Section A)}

The pollen grains are partly worn. The Pinus pollen grains are physically so degraded that 


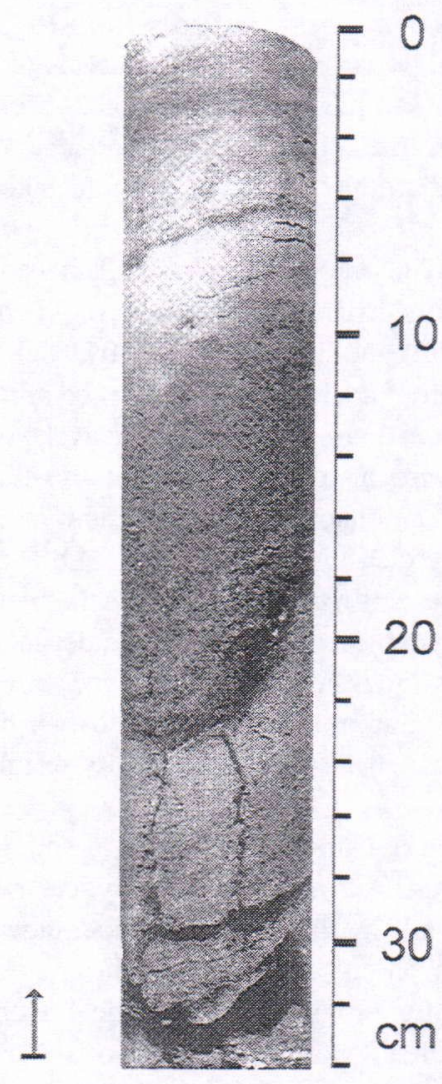

Figure 5. Diatomite block with varying abundance of coarse detritus gyttja. Photograph: J. Väätäinen 1995.

only a small proportion of grains with saccus parts remains. Many Betula pollen grains have thinned exine. Only in a few cases could the $B$. nana type be identified and so it was merely verified as present in the pollen flora. The lower part of the diatomite layer exhibits a large number of highly corroded triporate pollen grains, the majority probably of Betula type. They are marked separately in the pollen diagram as well as are some of the exotic pollen and spore types encountered (Fig. 7).

The distribution of pollen taxa permits stratigraphic differentiation of the diatomite layer. Two local pollen assemblage zones are distinguished.
Betula zone. Birch pollen dominates, with 49$64 \%$ of total pollen. Pine pollen accounts for 4 24\%. Sporadic pollen grains of Alnus, Carpinus, Quercus and Corylus are also encountered. In the lower part of the zone shrubs, dwarf shrubs and herbs account for $46 \%$ of total pollen. Their proportion diminishes in the upper part, where Lycopodium spores reach their maximum. The upper limit is defined by a distinct increase in pine pollen.

Pinus zone. The zone is characterized by the $64-91 \%$ dominance of pine pollen, birch values being under $20 \%$. Only one Alnus and two Corylus pollen grains were found. The amount of non-arboreal pollen (NAP) is rather low, except in the upper part of the zone, where it increases slightly. Abundances of fern pollen are elevated in the upper part of the zone.

The pollen spectra of the diatomite clearly represent a succession of plant communities, starting from early vegetational development. The pollen flora in the lower part of the Betula zone exhibits a maximum of NAP including shrubs (Salix, Myrica type), dwarf shrubs (Ericaceae undiff., Calluna and Bruckenthalia) and herbs. Herbs are represented by various taxa including Poaceae, Cyperaceae, Compositae undiff., Achillea -, Cirsium- and Aster type, Artemisia, Caryophyllaceae, Thalictrum, Ranunculus- and Rumex acetosa type, Filipendula, Melampyrum, Onagraceae and Polygonum sect. Persicaria. Birch is represented by a tree species and by dwarf birch. Pinus pollen values are low.

The pollen flora at the beginning of the Betula zone indicates more open birch forest, where open space was covered by shrubs, dwarf shrubs and herbs, among which plants with higher light requirements thrived. Later the birch forest became more closed. The first faint traces of pine are due to long-distance transport or to a sparse local occurrence.

In the following Pinus zone the proportion of Betula declines conspicuously. The amount of shrubs, dwarf shrubs and herbs also diminishes, particullary the pollen of Salix, Ericaceae, diverse Compositae types and Poaceae. Among the herbs surviving from the previous zone there are some new genera and species: Ranunculaceae undiff., Galium, Geranium, Myriophyllum alterniflorum 


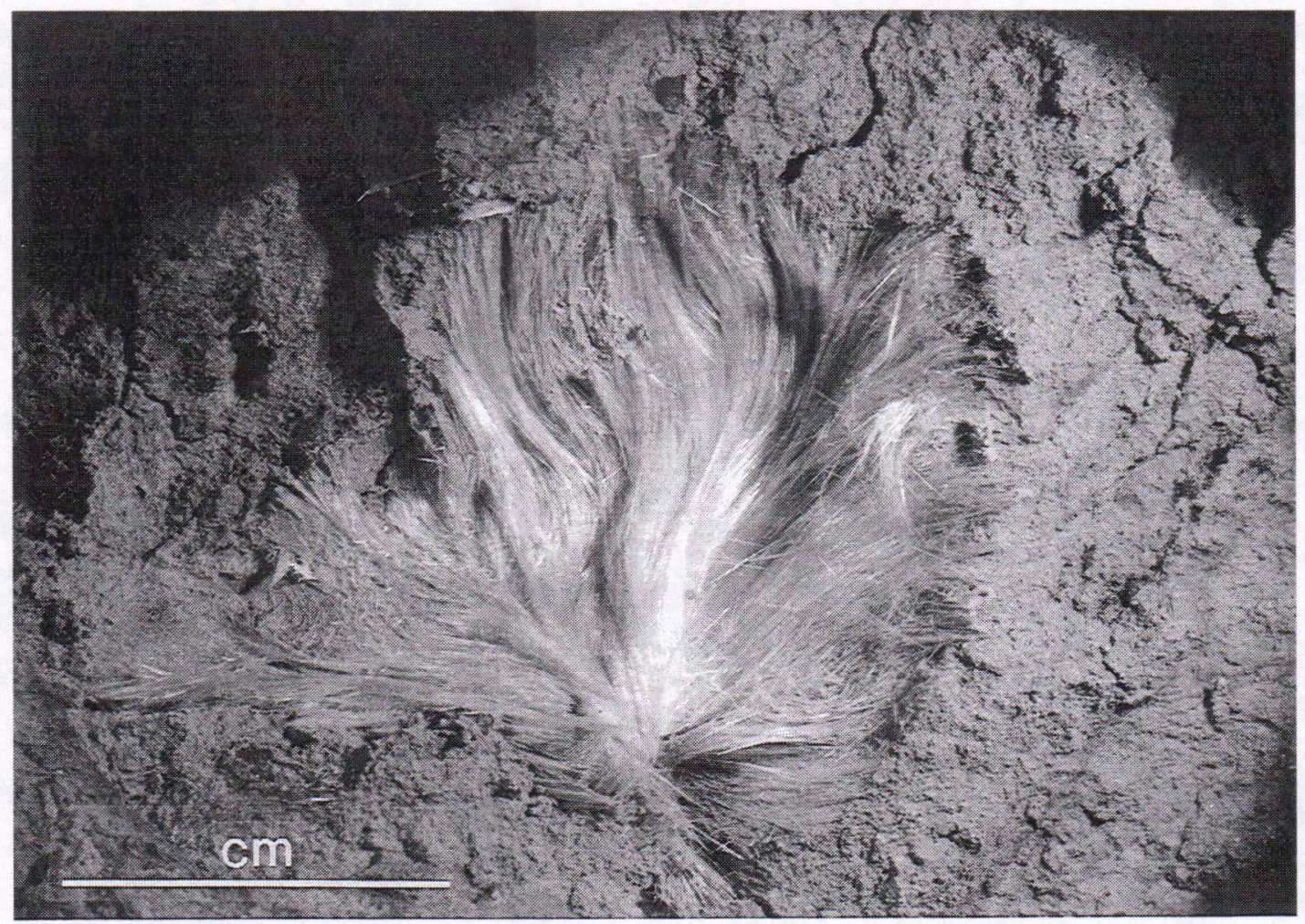

Figure 6. Layer with siliceous spicules of sponge. Photograph: J. Väätäinen 1995.

and Typha latifolia. The upper part of the sequence is marked by an increase in the abundance of Polypodiaceae. The proportion of Sphagnum spores also increases at the same levels.

The pollen flora in the Pinus zone reflects pine dominated closed forest, indicating more favourable climatic conditions than in the previous phase. The increase in the proportion of Polypodiaceae and Sphagnum may imply a slight increase in moist forest areas, which made conditions favourable for the formation of fern community patches.

The clear succession from open birch forest to closed pine forest indicates that the pollen spectra composed of Betula, Pinus and various NAP types are of local and regional origin. The sporadic finds of Carpinus, Quercus, Corylus in the strata (mostly in the Betula zone) are, however, of secondary origin as are the occurrences of Carya and unknown Vesiculate pollen types.
Silty clay layer (Unit 5, Section B)

The silty clay layer is very poor in pollen. Only two samples contained sufficient pollen for a meaningful percentage to be calculated (Fig. 8). The lower sample from the $60-\mathrm{cm}$ level contains a high abundance of Pinus pollen, $60 \%$, and $28 \%$ Betula. Carpinus, Quercus and Corylus are also represented among the pollen flora. The $50-\mathrm{cm}$ level reveals a $46 \%$ dominance of Alnus pollen, $23 \%$ Betula, 13\% Pinus, 1.6\% Carpinus $1.6 \%$ and $10 \%$ Corylus. NAP flora is very scanty in both samples.

The silty clay layer contains only a few pollen grains. Hence no conclusions can be drawn concerning the vegetation cover. There are more pollen grains in the middle of the sequence, where a loss-on-ignition curve also rises to its maximum. The pollen composition differs from the spectra in the diatomite 


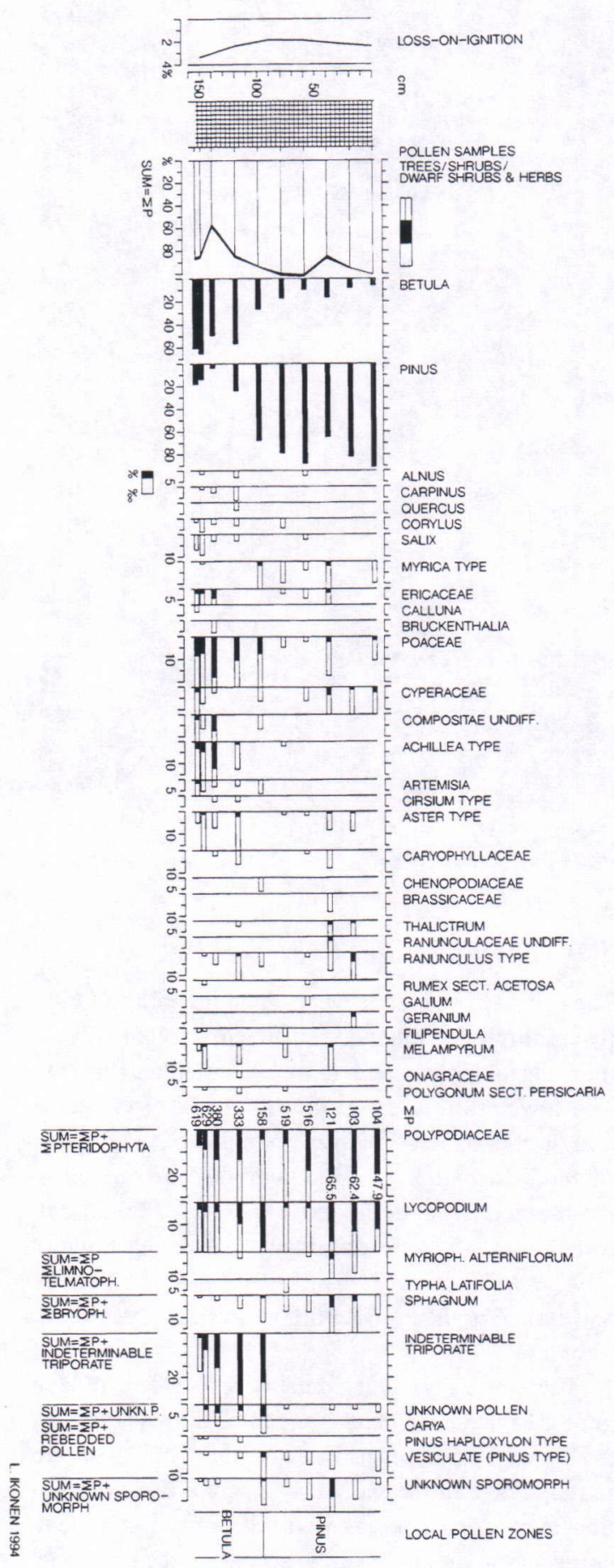

layer, indicating more temperate forest composition than that recorded in the diatomite layer; it resembles the Eemian pollen flora reported from the area (e.g. Eriksson 1993).

\section{Diatomite block with varying abundance of coarse detritus gyttja}

The cellular tissue remains in the diatomite samples are largely composed of Bryideae and Betula bark, although small pieces of Pinus and Salix bark were also found. The uppermost diatomite sample from a depth of 1-2 cm contained a large amount of Betula bark. The wood sticks found in the sequence are Salix twigs.

The pollen grains in the whole sequence are well preserved. One local pollen zone can be distinguished (Fig. 9). The pollen spectra, however, represent a certain succession of NAP. In the lower part of the sequence NAP values are higher, but diminish at the level where the losson-ignition curve rises for the second time. The principal tree genera are Pinus and Betula, of which the former is dominant. The Betula values are generally under $20 \%$, reaching $38 \%$ in only two samples. Sporadic Picea, Alnus, Carpinus, Fraxinus, Quercus, Ulmus pollen grains are also found. Pollen of Corylus occurs in slightly greater abundance than that of other deciduous trees. Shrub pollen is represented by Salix and Juniperus and dwarf shrub pollen by Betula nana, Ericaceae undiff. and Bruckenthalia. Asteraceae Cichoriaceae, Poaceae, Cyperaceae, Caryophyllaceae and Chenopodiaceae constitute the principal herbaceous spectra. Aquatic plants are represented by the almost ubiquitous Isoëtes and sporadic Myriophyllum and Polygonum amphibium occurrences.

The pollen assemblage suggests the presence of coniferous forest (exclusively Pinus) with patches of birch trees. The pollen flora indicating the occurrence of open areas with bush-grass communities is more abundant in the lower diatomite layer. The deciduous tree pollen assemblage is alien to the rest of the pollen flora, which indicates redeposition. 


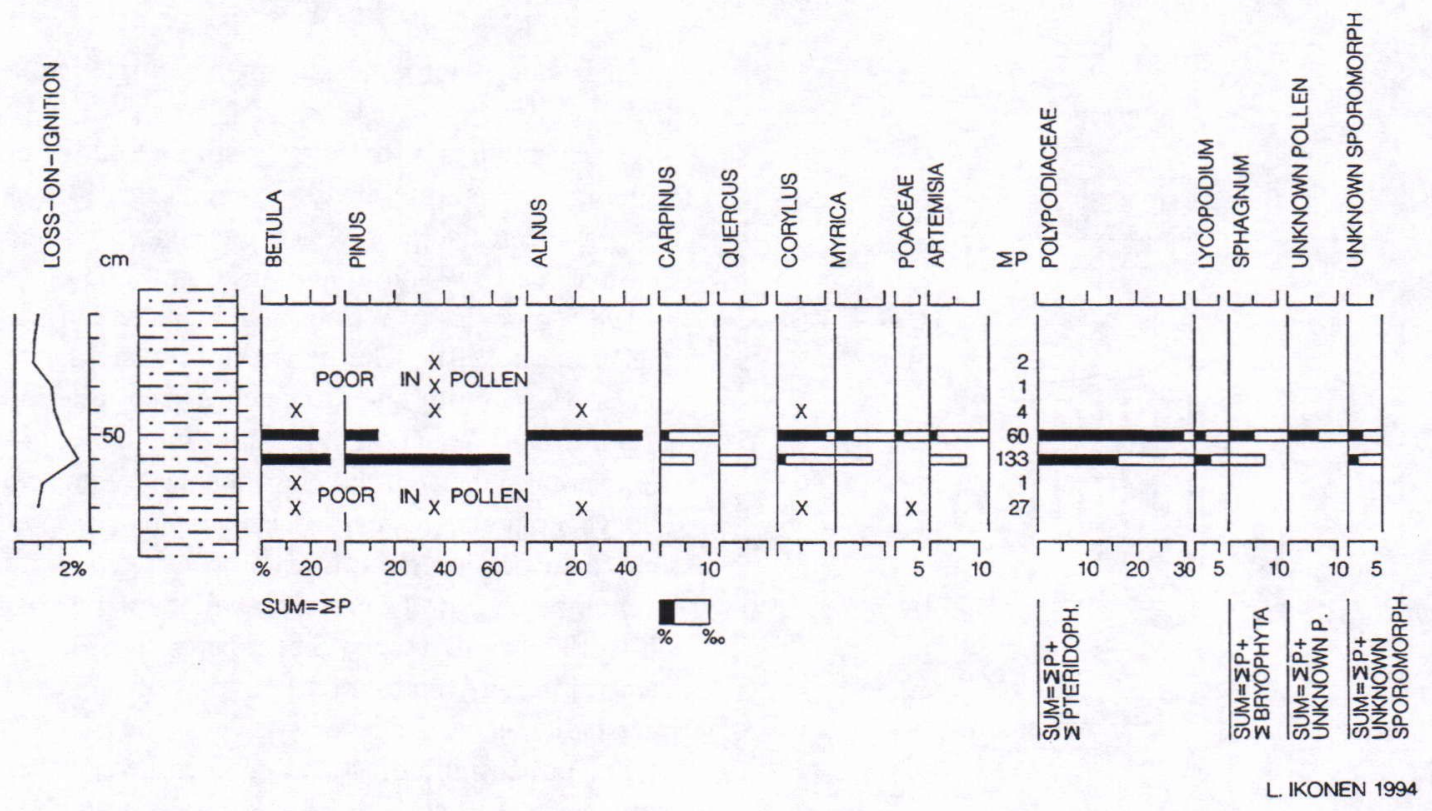

Figure 8. Pollen diagram from Horonpää silty clay layer (Section B). Sediment symbols in Fig. 3.

The above pollen grains are much better preserved than those in the diatomite layer (Unit 2, Section A). The composition of the pollen spectra, however, differs only slightly from that of the flora of the Pinus assemblage zone in the diatomite layer. The difference is due to the occurrence of sporadic deciduous tree pollen grains, which are concentrated in the Betula assemblage zone, and to he absence of Picea pollen. The proportions of Polypodiaceae and Lycopodium pollen in contrast, are higher in the diatomite layer.

The differences between the loss-on-ignition curves (Figs 7 and 9) show that the diatomite layer and the block were not deposited in the same place. The fluctuation in the water level demonstrated by the variation in the abundance of coarse detritus gyttja in the diatomite block suggests that the sequence was probably laid down nearer the shore than the diatomite layer, which was deposited farther off in the same water body.

\section{Correlation of pollen data}

The pollen flora of the diatomite layer from the Horonpää sequence displays an obvious vegeta- tional succession with apparent similarities to the successions at Oulainen (Forsström 1982 and 1988, Donner 1988) and Marjamurto (Peltoniemi et al. 1989) interstadial sites, both of which are interpreted as representing an Early Weichselian interstadial, the Brörup. The pollen flora from the Oulainen sequence records development from an initial birch forest to denser pine forest, which was later replaced by more open birch forest. The last vegetational phase depicted at Oulainen is, however, absent from the Horonpää sequences (Fig. 10).

The very early vegetational phase is not present in the Marjamurto pollen flora. The first phase already shows a closed forest type with birch and pine and some alder at damper sites (Peltoniemi et al. 1989). In the Horonpää profile the sporadic Alnus pollen grains possibly indicate only a sparse local presence of this species. According to Forsström (1988), at the Oulainen site, Alnus pollen does not imply a local presence. Donner (1988), however, reported the presence of alder in the pine forest phase at Oulainen. Sporadic Picea pollen are found in both the Oulainen and Marjamurto se- 


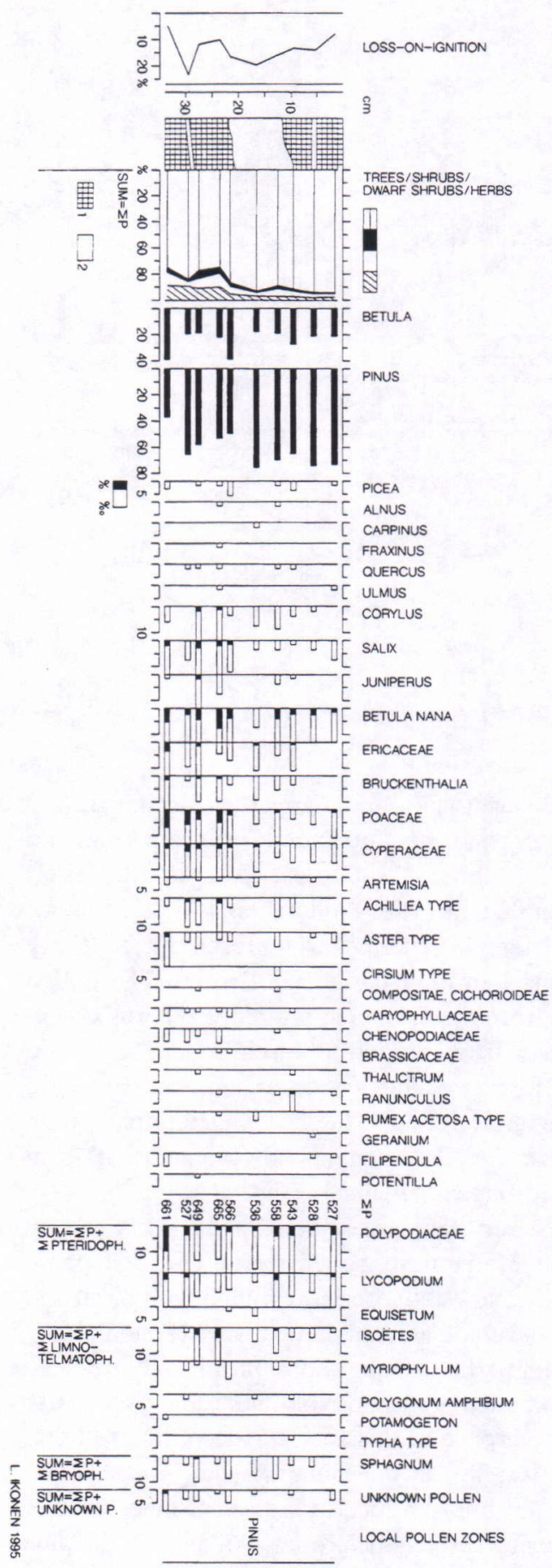

quences, but at Horonpää only in the samples from profile C.

At Harrinkangas, the clayey silt and silt layer with organic bands in the till-covered esker formation has been interpreted as representing the late Eemian / early Weichselian transition (Gibbard et al. 1989) or an Early Weichselian interstadial (Kujansuu et al. 1991). The pollen flora is similar to that at Marjamurto and Oulainen, except that the proportion of Picea pollen is somewhat higher (4 $6 \%$ of total pollen) in the Harrinkangas sequence. The vegetational history of Harrinkangas represents a succession from a boreal forest type with birch, pine and spruce to a regional grassland possibly of tundra-like type (Gibbard et al. 1989). The succession may represent a later part of the same interstadial as the Oulainen site.

The pollen flora of the till-covered layer of organic sediment at Vimpeli (Vimpeli I), with a Betula maximum followed by a Pinus-dominated assemblage (Aalto et al.1983), also shows similarities to the flora at Horonpää. The section was earlier thought to represent an initial stage of the Eem interglacial or an interstadial (Aalto et al 1983) but it was later confirmed to represent the Oulainen interstadial (Donner 1983 and 1988, Aalto et al. 1989). According to Donner (1988), compared with the Oulainen the Vimpeli sequence represents the lower half of the interstadial.

The pollen flora of the Horonpää diatomite also resembles the vegetational succession of the tillcovered gyttja layer at Virtasalmi (Jokinen et al. 1993). The difference in the pollen record between these two sites is due to the abundance of Alnus and Picea pollen grains, which are found only sporadically in the Horonpää diatomite layers. According to Jokinen et al., the preliminary biostratigraphic results do not permit the pollen stratigraphy of Virtasalmi sequence to be correlated with any interglacial or interstadial stages. The till stratigraphy may, however, imply of an older age than the Eemian interglacial.

The vegetational succession in the Horonpää diatomite layer bears no similarities to the Eemian pollen stratigraphy of Ostrobothnia, where the initial Betula-dominated closed forests were immediately succeeded by a Betula-Pinus-Quercus for- 


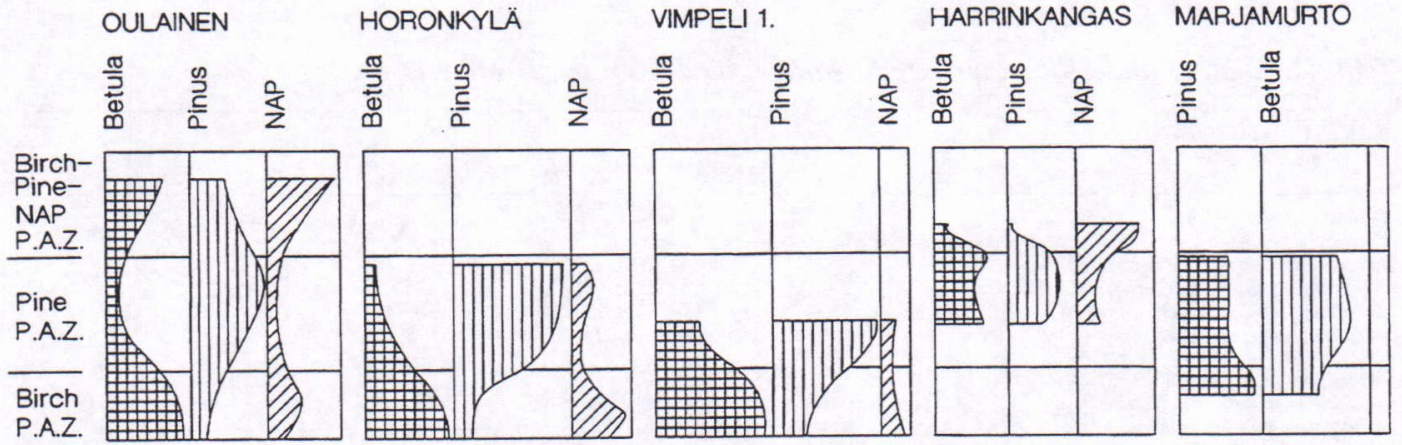

Figure 10. Schematic interstadial pollen diagrams from deposits in Ostobothnia with zoning used.

est community (Eriksson 1993, Eriksson \& Kujansuu 1994).

A Betula-dominated interstadial has also been established for central Ostrobothnia (Iisalo 1992, 1996). According to Iisalo, the Mertuanjoki esker formation between the upper and lower tills at Ylivieska was probably formed during the Weichselian interstadial. The lower silty till in central Ostrobothnia is the same till that covers the Early Weichselian interstadial and the Eemian interglacial deposits in the area. The pollen flora of the silty sand and the organic-bearing layer, which are located between the Ylivieska esker formation and the overlying till, is dominated by Betula with a few per cent of Pinus, Alnus, Picea and Corylus pollen. The macrofossil flora of the organic-bearing layer consists of B. nana, Salix, Empetrum nigrum, many different Bryideae species and also a few seeds of water plants. According to its stratigraphic position, Mertuanjoki possibly represents an Odderade type of interstadial.

According to Forsström's model (1988), the Mertuanjoki site lies inside the Odderade pine limit. The pine phase is not, however, displayed in the pollen flora and it is possible that only a part of the interstadial has been preserved.

\section{Diatom record}

Whenever possible at least 500 diatom valves were identified in each subsample. The diatom taxa encountered are listed in Table 1. Some taxa have been transferred to new genera by Round et al. (1990). Those new names are added to the diatom list. The most characteristic diatom genera and taxa of both layers are presented in diagrams. The diagram in Fig. 11 shows the diatoms of the diatomite layer. The diatom zones (DZ1-4) of the diatomite layer were created on the basis of the changes in diatom assemblages. The $\mathrm{pH}$ spectra and main habitats of the diatoms are shown in Figs 12 and 13. Figure 14 presents the most characteristic diatom genera and taxa of the silty-clay layer.

\section{Diatomite layer (Unit 2, Section A)}

Twenty-five diatom genera and 94 taxa were identified. All diatoms found are freshwater species. Excluding the lowermost samples, alkaliphilous diatoms are dominant throughout the sequence. The profile is divided into four diatom zones (DZ1-4) (Fig. 11).

Diatom zone 1 (depth 140-155 cm). Small planktonic Aulacoseira distans type diatoms, possibly Aulacoseira distans (Ehrenberg) Simonsen and/or A. distans var. alpigena (Grunow) Simonsen, are clearly dominant (59-85\%) and are called the Aulacoseira distans group. A. italica (Ehrenberg) Simonsen, A. valida (Grunow) Grammer, $A$. subarctica (Müller) Haworth and Fragilaria virescens Ralfs are quite common. A. distans and $A$. distans var. alpigena are classified as acidophilous 
Table 1. Diatom and Silicoflagellate Taxa identified from the Horonpää site.

\section{DIATOMITE DEPOSIT}

$\begin{array}{llllllllllllllllll}\text { Depth cm } & 0 & 5 & 15 & 25 & 35 & 45 & 55 & 65 & 75 & 85 & 95 & 105 & 115 & 125 & 135 & 145 & 155\end{array}$

Diatoms:

Achnanthes elliptica Cleve

Achnanthes kryophila Petersen

Achnanthes lanceolata (Brébisson) Grunow

Achnanthes lanceolata var. rostrata (Oestrup) Hustedt

Achnanthes levanderi Hustedt

Achnanthes linearis (Smith) Grunow

Achnanthes minutissima Kützing

Achnanthes nodosa Cleve-Euler

Achnanthes oblongella Oestrup

Achnanthes spp.

Amphora ovalis Kützing

Anomoeoneis brachysira (Brébisson) Grunow

Aulacoseira distans group

Aulacoseira islandica (Müller) Simonsen

Aulacoseira italica (Ehrenberg) Simonsen

Aulacoseira lacustris (Grunow) Krammer

Aulacoseina subarctica (Müller) Haworth

Aulacoseira valida (Gnunow) Krammer

Aulacoseira sp.

Caloneis silicula (Ehrenberg) Cleve

Cocconeis euglypta Ehrenberg

Cocconeis placentula Ehrenber

Cymbella aspera (Ehrenberg) Peragalli

Cymbella cesatii (Rabenhorst) Grunow

Cymbella cuspidata Kützing

Cymbella naviculiformis Auerswald

Cymbella ventricosa Kützing

Diatoma anceps (Ehrenberg) Kirchner

Ellerbeckia arenaria (Moore) Crawford

Epithemia adnata (Kützing) Rabenhorst

Epithemia adnata var. porcellus (Kützing) Ross

Epithemia sorex Kützing

Epithemia turgida (Ehrenberg) Kützing

Epithemia turgida var. granulata (Ehrenberg) Brun

Eunotia arcus Ehrenberg

Eunotia implicata Nörpel \& Lange-Bertalot

Eunotia incisa Gregory

Eunotia lunaris (Ehrenberg) Grunow

Eunotia monodon Ehrenberg

Eunotia naegelii Migula

Eunotia tenella sensu (Grunow) Cleve

Eunotia sp.

Fragilaria bicapitata Mayer

Fragilaria bidens Heiberg

Fragilaria brevistriata Grunow = Pseudostaumsira

brevistriata (Grunow) Williams \& Round

Fragilaria capucina Desmazières

Fragilaria constricta Ehrenberg = Fragilariforma const-

ricta (Ehrenberg) Williams \& Round

Fragilaria construens (Ehrenberg) Grunow = Stau-

rosira construens (Ehrenberg) Williams \& Round

Fragilaria construens var. venter (Ehrenberg) Grunow

Fragilaria lapponica Grunow = Staumsirella lapponica

(Grunow) Williams \& Round

Fragilaria pinnata Ehrenberg = Staumsirella pinnata

(Ehrenberg) Williams \& Round

Fragilaria rumpens (Kützing) Carlson

Fragilaria rumpens var. fragilarioides Gnunow

Fragilaria virescens Ralfs = Fragilariforma virescens

(Ralfs) Williams \& Round

Frustulia rhomboides (Ehrenberg) De Toni

Frustulia vulgaris (Thwaites) De Toni

Gomphonema acuminatum Ehrenberg

Gomphonema acuminatum var. comnatum (Ehrenberg)

Smith

Gomphonema angustatum (Kützing) Rabenhorst

Gomphonema augur Ehrenberg

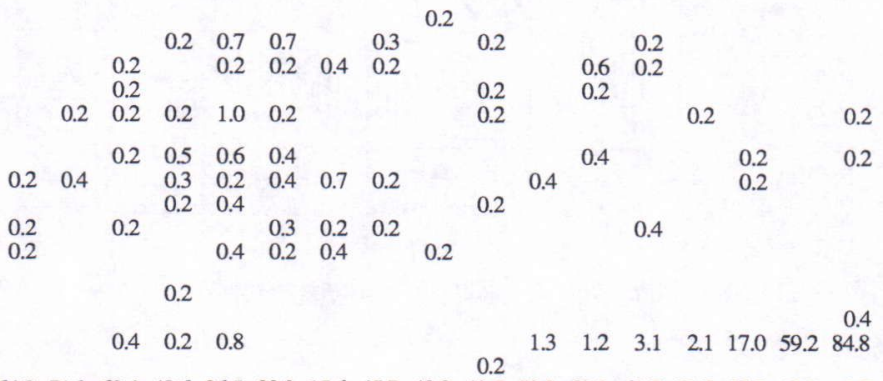

$\begin{array}{lllllllllllllllll}64.8 & 71.0 & 60.4 & 48.6 & 26.5 & 23.3 & 15.6 & 45.7 & 43.2 & 40.5 & 58.3 & 60.9 & 61.7 & 81.2 & 55.2 & 18.8 & 0.7\end{array}$

03

1.9

$3.2 \quad 18 \quad 19 \quad 1.0$

0.2

0.2

0.2

0.2

0.2

0.2

$0.2^{0.2}$

0.2

0.6

$\begin{array}{llll}0.4 & 1.1 & 0.2 & 0.2\end{array}$

0.2

$\begin{array}{llll} & 0.5 & 0.2 & 0.6 \\ & 0.2 & 0.3 & \\ 0.2 & & & \end{array}$
0.2

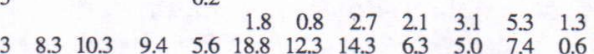


Early Weichselian biostratigraphy and vegetational 73

\begin{tabular}{|c|c|c|c|c|c|c|c|c|c|c|c|c|c|c|c|c|c|c|}
\hline & Depth cm & 0 & 5 & 15 & 25 & 35 & 45 & 55 & 65 & 75 & 85 & 95 & 105 & 115 & 125 & 135 & 145 & 155 \\
\hline $\begin{array}{l}\text { Gomphonema constrictuon Ehrenberg } \\
\text { Gomphonema gracile Ehrenberg }\end{array}$ & & & 0.2 & & 0.2 & 0.4 & 0.3 & & 0.2 & & 0.2 & 0.3 & & 0.2 & 0.2 & 0.2 & & \\
\hline Gomphonema parvulum (Kützing) Grunow & & 0.2 & & 0.2 & & 1.0 & 0.2 & 0.4 & 0.3 & 0.2 & & 0.7 & 1.0 & 0.6 & 0.5 & 0.2 & 0.2 & 04 \\
\hline $\begin{array}{l}\text { Gomphonema sphaerophorum Ehrenberg } \\
\text { Gomphonema spp. }\end{array}$ & & 0.2 & & & & 0.6 & & 0.2 & & & & & 0.2 & & & & & \\
\hline
\end{tabular}

Hantzschia amphioxys (Ehrenberg) Grunow

Meridion circulare var. constricta (Ralfs) Van Heurck

Navicula amphibola Cleve

Navicula cryptocephala Kützing

Navicula exigua Grunow

0.2

0.2

Navicula psendoscutiformis Hustedt $=$ Cavinula pseudos cutiformis (Hustedt) Mann \& Stickle

Navicula pupula Kützing = Sellaphora pupula (Kützing)

Mereschkowsky

Navicula radiosa Kützing

Navicula sp.

Neidium iridis fo. vernalis Reichelt \& Hustedt

Nitzschia archibaldii Lange-Bertalot

Nitzschia frustulum (Kützing) Grunow

Nitzschia sp.

Pinnularia borealis Ehrenberg

Pinnularia gibba Ehrenberg

Pinnularia gibba var. linearis Hustedt

Pinnularia hemiptera (Kützing) Rabenhorst

Pinnularia interrupta Smith

Pinnularia mesolepta (Ehrenberg) Smith

Pinnularia microstauron (Ehrenberg) Cleve

Pinnularia nodosa (Ehrenberg) Smith

Pinnularia rupestris Hantzsch

Pinnularia ruttneri Hustedt

Pinnularia stomatophora (Grunow \& Schmidt) Cleve

Pinnularia subcapitata Gregory

Pinnularia subsolaris (Grunow) Cleve

Pinnularia viridis (Nitzsch) Ehrenberg

Pinnularia viridis var. sudetica (Hilse) Hustedt

Pinnularia spp.

Rhopalodia gibba (Ehrenberg) Müller

Staunoneis anceps Ehrenberg

Stauroneis phoenicenteron Ehrenberg

Synedra ulna (Nitzsch) Ehrenberg

Synedra sp.

Tabellaria fenestrata (Lyngbye) Kützing

Tabellaria flocculosa (Roth) Kützing

Tetracyclus emarginatus (Ehrenberg) Smith

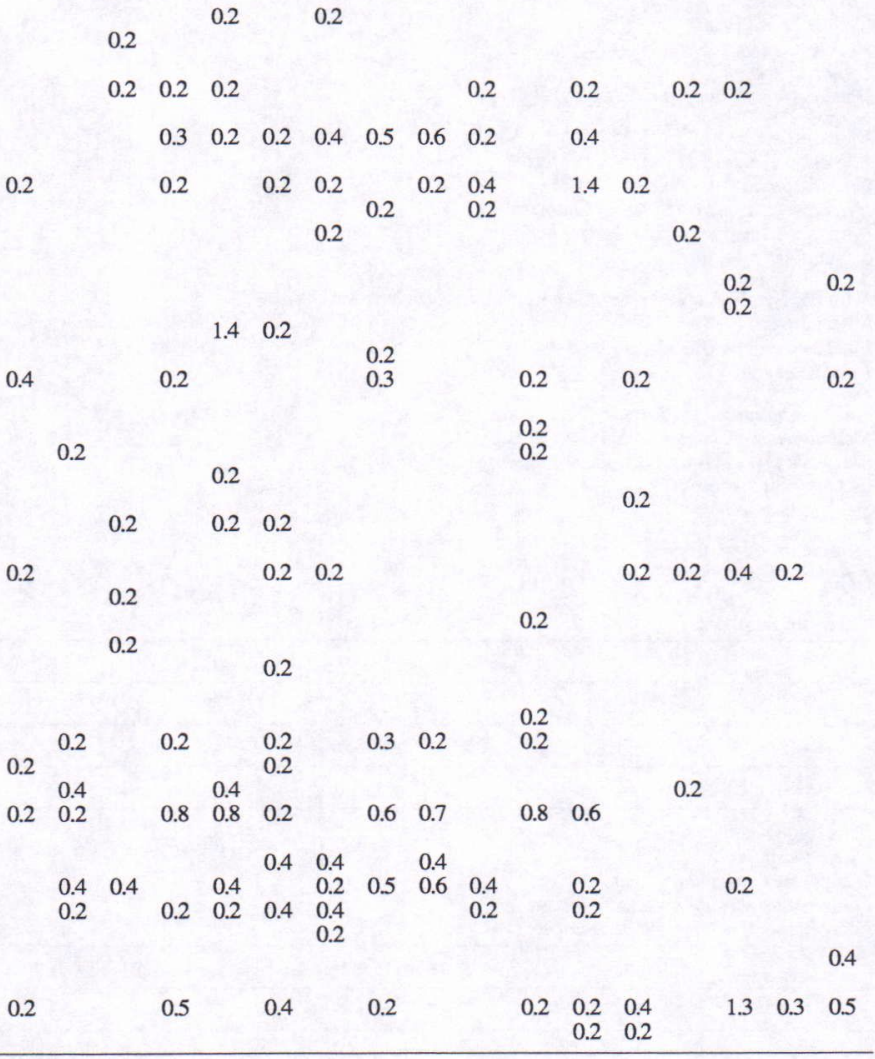

$\begin{array}{llllllllllllllllll}\% & 100 & 100 & 100 & 100 & 100 & 100 & 100 & 100 & 100 & 100 & 100 & 100 & 100 & 100 & 100 & 100 & 100\end{array}$

$\begin{array}{lllllllllllllllll}520 & 550 & 520 & 595 & 510 & 550 & 530 & 600 & 530 & 540 & 550 & 510 & 510 & 570 & 540 & 670 & 520\end{array}$ 


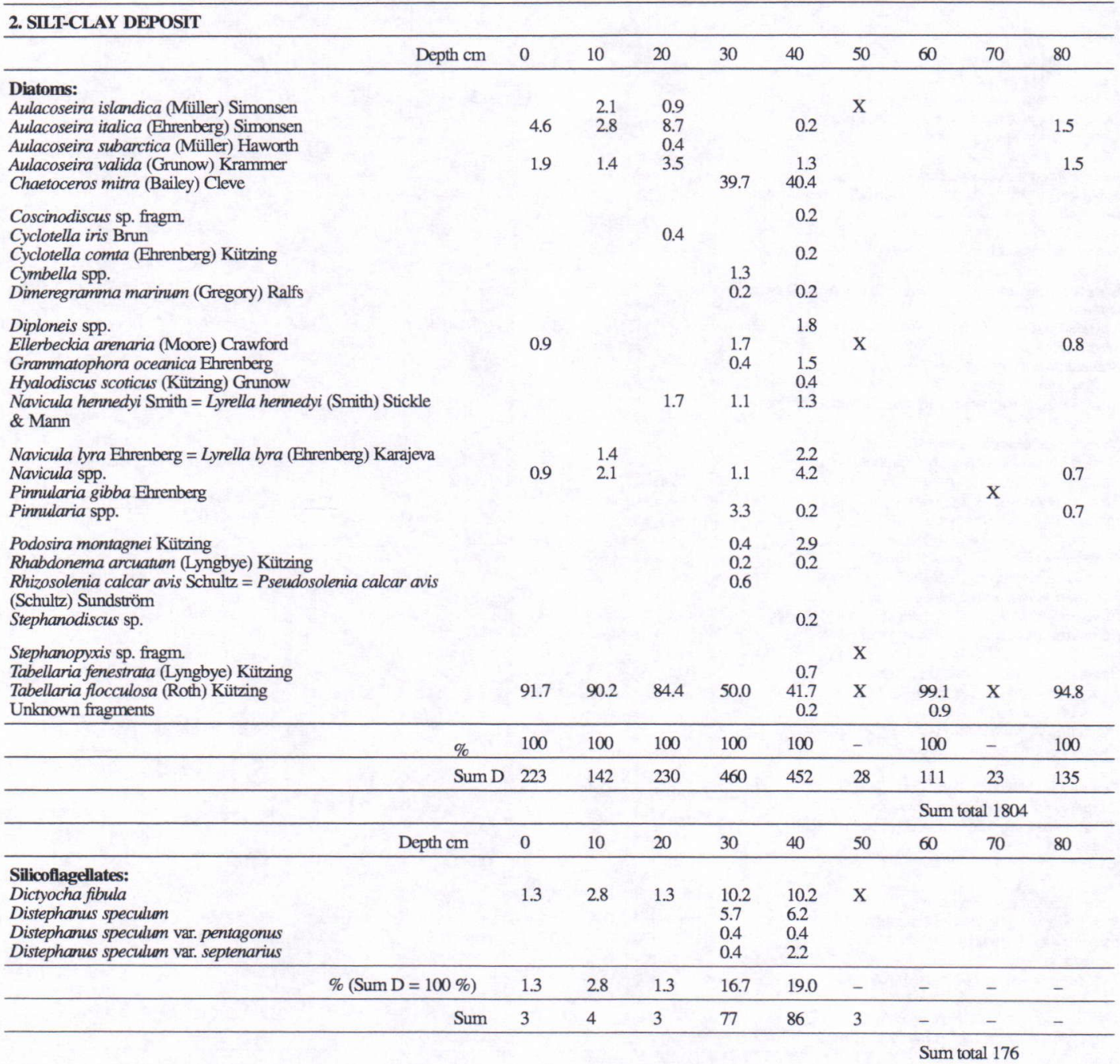

$\mathrm{X}=$ species noted in the sample

The new names according to Round, F.E., Crawford, R.M. and Mann, D.G. 1990. The diatoms Biology and morphology of the genera. Cambridge University Press, Cambridge, $747 \mathrm{p}$.

taxa (Foged 1958, Haworth 1969, Renberg 1978) but also as alkaliphilous taxa (Foged 1964, Renberg 1976). The Aulacoseira distans group is here classified as acidophilous. The other Aulacoseira species mentioned are alkaliphilous (Foged 1958).

There are also some Eunotia taxa (e.g. Eunotia arcus Ehrenberg, E. implicata Nörpel \& Lange-Bertalot, E.tenella (Grunow) Cleve), Frustulia rhomboides (Ehrenberg) De Toni and Gomphonema parvulum (Kützing) Grunow, indicating an acid-neutral milieu.
Diatom zone 2 (depth 90-140 cm). Alkaliphilous diatoms are dominant in zone 2. Aulacoseira italica is the most common species but and $A$. valida and $A$. subarctica are also common. The abundance of species of the $A$. distans group decreases distinctly, but that of Fragilaria species such as $F$. brevistriata Grunow, $F$. construens (Ehrenberg) Grunow and $F$. construens var. venter (Ehrenberg) Grunow increases. Epithemia taxa also make their appearance in the diatom flora. 


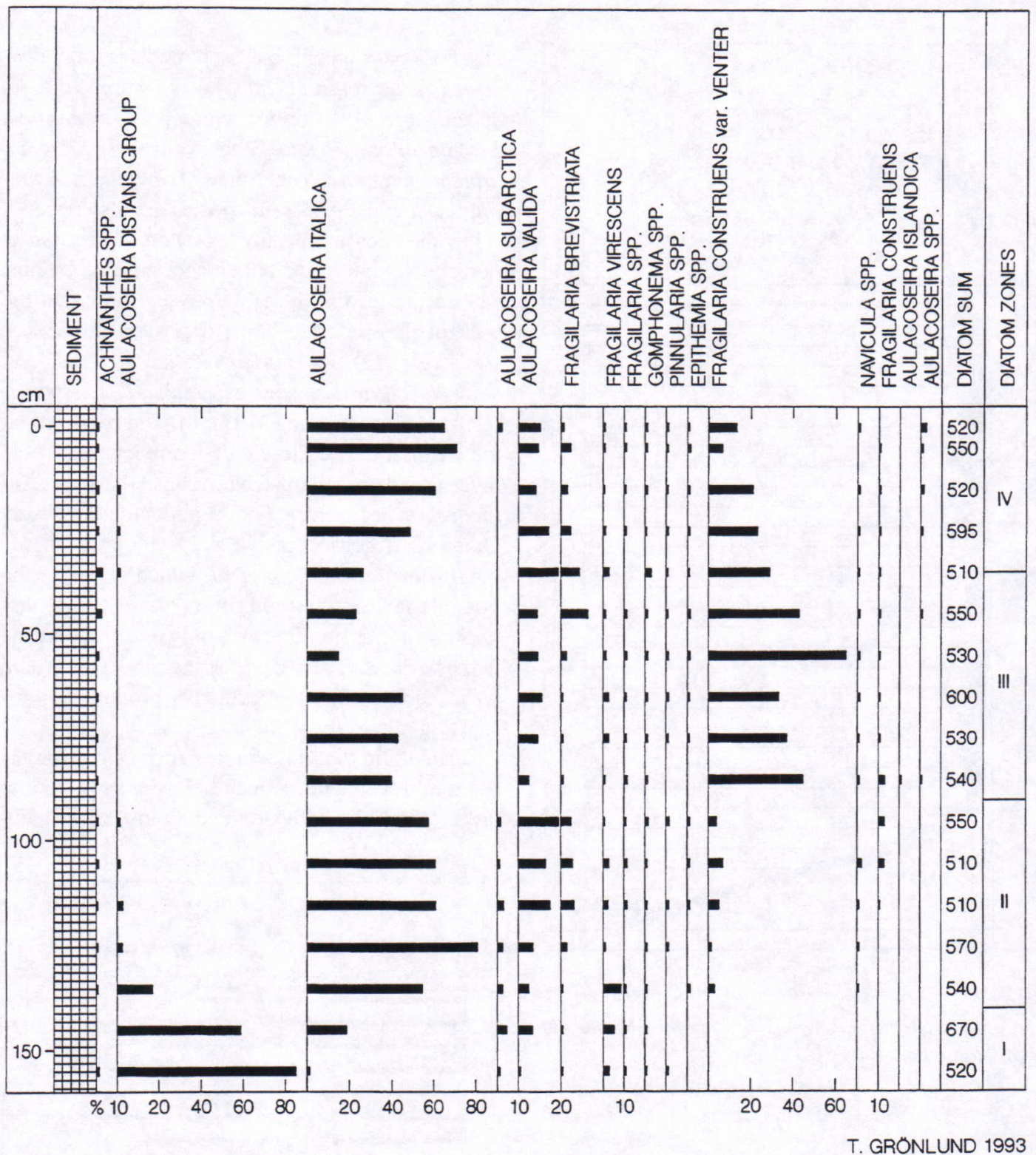

Figure 11. The most caracteristic diatoms from the Horonpää diatomite layer. Sediment symbols in Fig. 3.

Diatom zone 3 (depth $45-85 \mathrm{~cm}$ ). This zone is characterized by broken and degraded diatom frustules. Fragilaria species in particular tend to be very fragmentary and so may be under-represented in the diatom data on this zone. The small epiphytic and alkaliphilous Fragilaria construens var. venter is the most common species. Other Fragilaria species are $F$. brevistriata, $F$. construens, $F$. lapponica Grunow, $F$. pinnata Ehrenberg and $F$. virescens Ralfs, all of which are known to prefer nutrient-rich (alkaline, eutrophic) conditions. High Fragilaria values are also characteristic of shallow 


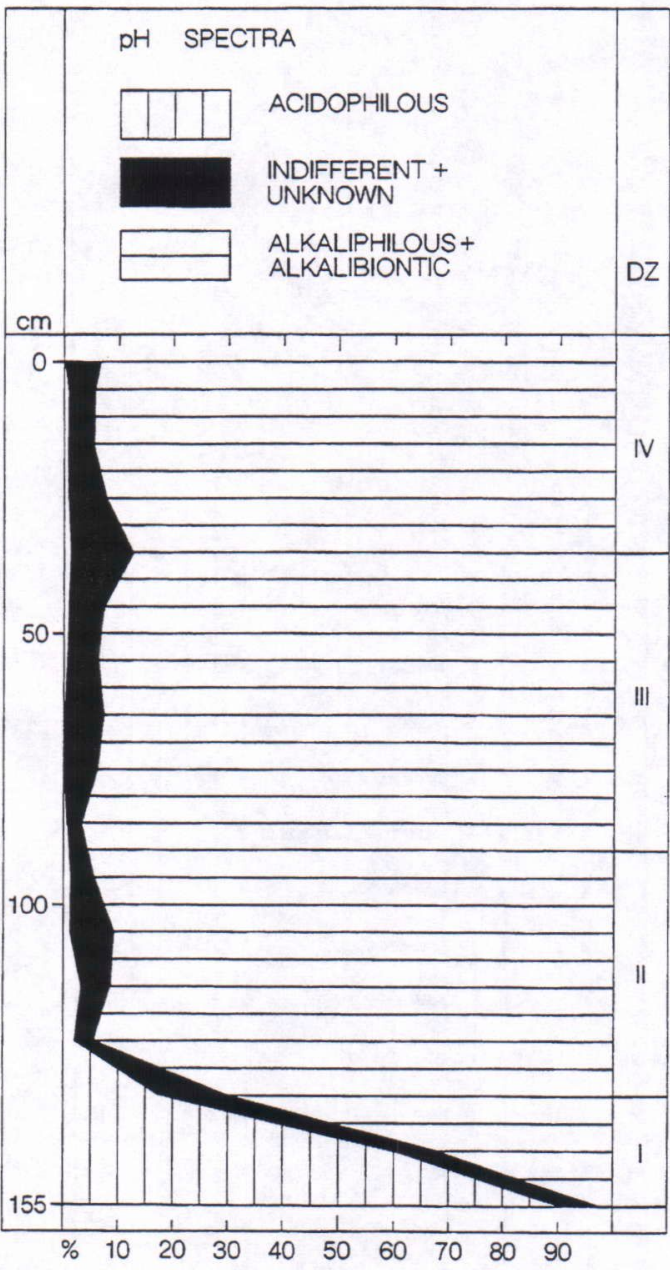

Figure 12. The pH-spectra of the diatoms from the $\mathrm{Ho}$ ronpää diatomite layer.

freshwater conditions (Miller 1971). Aulacoseira italica and $A$. valida are still fairly common. Alkalibiontic Epithemia adnata (Kützing) Rabenhorst, E. adnatata var. porcellus (Kützing) Ross, - $E$. sorex Kützing, E. turgida (Ehrenberg) Kützing and E. turgida var. granulata (Ehrenberg) Brun and indifferent Navicula pupula Kützing and $N$. radisosa Kützing are also present.

Diatom zone 4 (depth 0-35 cm). Aulacoseira italica and Fragilaria construens var. venter are still dominant species but the abundance of $F$. construens is decreasing. Other fairly common diatom species are Aulacoseira valida, A. subarctica, Fragilaria brevistriata, $F$. virescens and Epithemia adnata var. porcellus. Some Achnanthes, Gomphonema and Pinnularia species are also occur.

In the diatom spectra a certain succession is perceptible, but in the pollen spectra it is obvious. The results of the diatom analyses show that the bulk of the diatomite layer deposited in alkaline water (Fig. 12). Aulacoseira italica, A. valida and some Fragilaria species especially $F$. construens var. venter, are dominant. The trophic condition of the basin at the beginning of sedimentation of the layer cannot be established because the small $\mathrm{Au}$ lacoseira species have not been identified for sure. Opinions differ about the $\mathrm{pH}$ ecology of Aulacoseira distans var. alpigena, which is one of the possible taxa in question. In any case, the $A$. distans group was dominant for only a very short time in the basin. As species preferring more or less acid water, their decline was probably promoted by increasing alkalinity of the lake basin.

Planktonic diatom taxa are dominant throughout zones 1,2 and 4 in the Horonpää diatomite layer (Fig. 13). Planktonic diatoms are usually

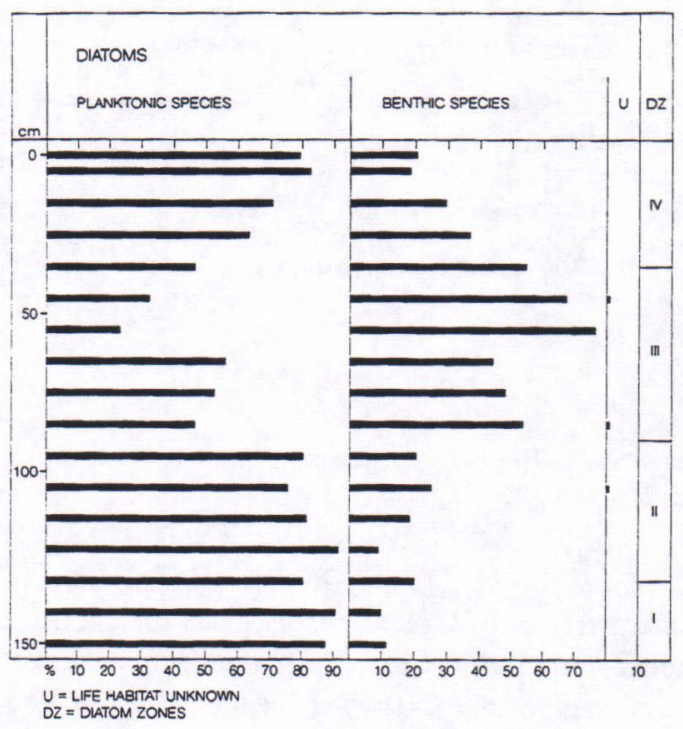

Figure 13. The life habitat of the diatoms from the Horonpää diatomite layer. $U=$ life habitat unknown. 
considered to indicate a deep water body. The Horonpää diatomite may not, however, have deposited in a very deep basin, because Aulacoseira taxa, which are the only planktonic species found in this flora, thrive not only as plankton but also as benthic species. Fluctuations in the curve of the main habitat of the diatom taxa (Fig. 13), however, may indicate at least slight water-level changes during sedimentation of the diatomite. Aulacoseira taxa are dominant in the bottom and upper parts of the sequence, suggesting a fairly high water level. The large amounts of epiphytic species, Fragilaria in particular, together with some benthic species indicate a lower water level in the middle part of the sequence. Thus, an increase in the numbers of littoral forms may indicate regression at a level of about $90 \mathrm{~cm}$, and a decreased transgression at a level of $35 \mathrm{~cm}$ (Digerfelt 1975).
The separate diatomite block (Section C)

Diatoms in the upper part of the core are very fragmentary, especially Fragilaria. Aulacoseira italica is clearly dominant as it is in the main part of the diatomite layer (unit 2). The diatom flora seems to correspond to that found in zone 2 and at the beginning of zone 3 (Unit 2).

\section{Silty clay layer (Unit 5, Section B)}

Excluding its middle part, the silty-clay layer has contains a few diatoms (Fig. 14). Only 18 diatom genera and 18 taxa were identified. Some silicoflagellates, which are marine plankton algae, were also encountered. Siliceous spicules of sponges are abundant in the upper part of the layer.

There are some interesting features in the diatom assemblage. Freshwater Tabellaria Ehrenberg

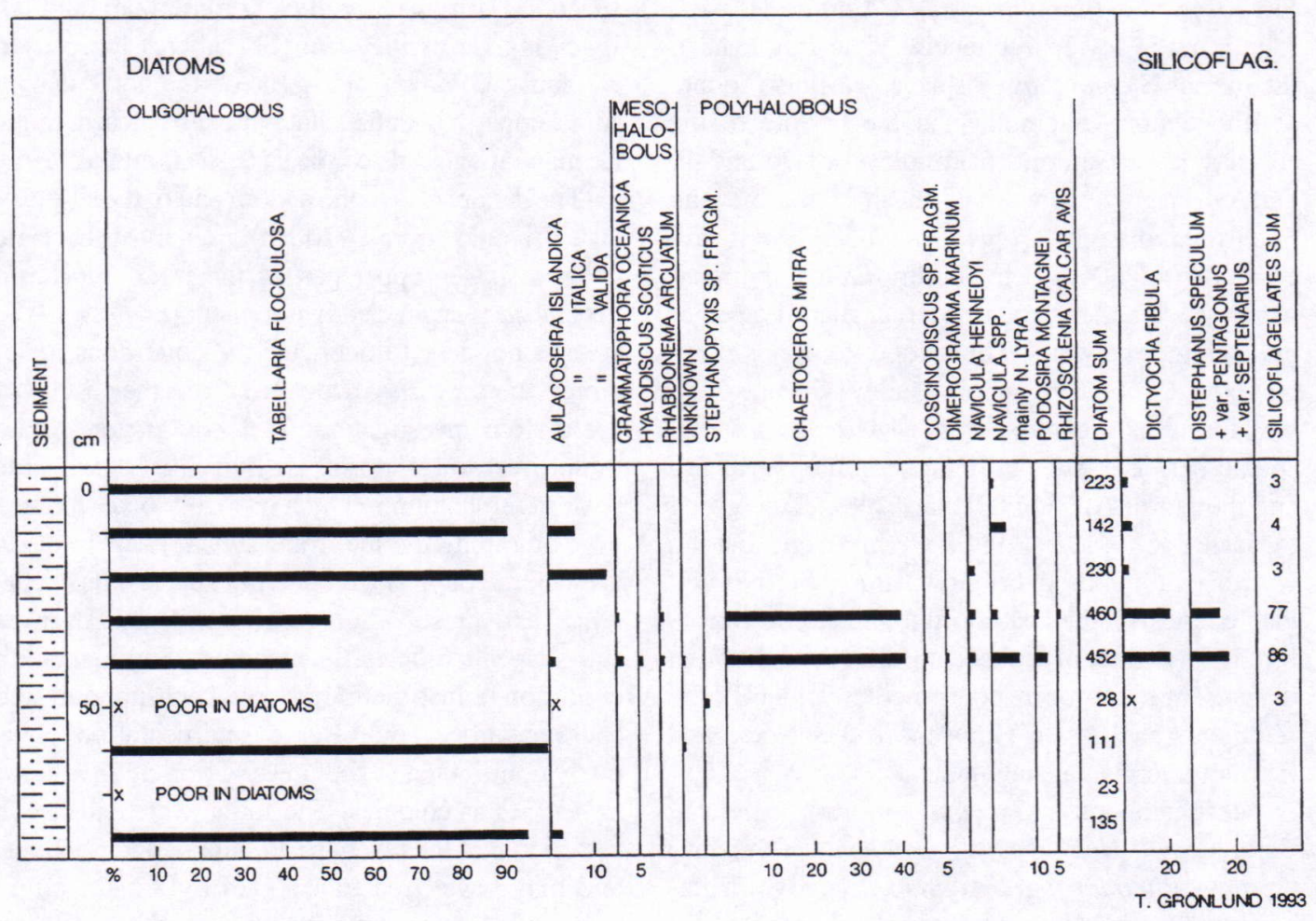

Figure 14. Main diatoms and silicoflagellates in the Horonpää silty clay layer. The percentages of silicoflagellates were calculated from the total sum of the diatoms/sample. Sediment symbols in Fig. 3. 
species dominate the layer throughout. The Tabellaria frustules were predominantly in girdle view or as colonies (cf. Figs 1-4 in Plate 1), and so were difficult to identify. Only zigzag colonies were found. Because zigzag colony morphology is typical of $T$. flocculosa (Roth) Kützing and not the straight-line colonies of $T$. fenestrata (Lyngbye) Kützing (Knudson 1952, Patrick \& Reimer 1966), the Tabellaria frustules found in the silty clay layer are named $T$. flocculosa. Star-shaped colonies, characteristic of both above taxa, were also found. T. flocculosa, either attached or planktonic, is widely distributed in different types of water. According to Patrick \& Reimer (1966), the specimens with longer frustules prefer oligotrophic to mesotrophic waters.

In addition to the clearly dominant Tabellaria flocculosa, some other freshwater frustules such as Ellerbeckia arenaria (Moore) Crawford, Aulacoseira italica, A. valida, A. islandica (Müller) Simonsen and Pinnularia gibba Ehrenberg were found, but in lower frequencies. One fragment of the marine Stephanopyxis species was also found.

The diatom assemblage in the middle of the silt-clay layer (samples from a level of 30 and 40 $\mathrm{cm}$ ) consists of about half-and-half marine and freshwater diatoms. Tabellaria flocculosa is still common (42-50\%), being is almost the only freshwater species. About ten different diatom species indicate marine water. The most common is polyhalobous Chaetoceros mitra (Bailey) Cleve, which was found as resting spores. C. mitra is a widespread neritic species in polar seas, the North Sea and the North Atlantic (Hendey 1964). According to Hasle \& Syvertsen (1990), it is an Arctic diatom, with a continuous distribution along the Norwegian coast from the Oslo fjord to the Arctic Ocean. It may be extinct in the recent Baltic Sea, although its presence has been confirmed in older Baltic sediments such as in Holocene Litorina Sea and Eemian interglacial sediments.

Mesohalobous Grammatophora oceanica Ehrenberg, Hyalodiscus scoticus (Kützing) Grunow, Rhabdonema arcuatum (Lyngbye) Kützing and polyhalobous Navicula hennedyi W. Smith, $N$. lyra Ehrenberg and Podosira montagnei Kützing species were identified. They have also been found in Eemian deposits in Finland and surrounding areas (Grönlund 1991). Some fragments of Coscinodiscus and Rhizosolenia calcar avis Schultze were also found. Many Navicula species, probably $N$. lyra or $N$. lyroides Hendey, were very corroded (cf. Fig. 4 in Table 2) and are thus included under the name Navicula spp. There are also badly dissolved Diploneis species under the name Diploneis spp., and unidentified fragments. Some Diploneis species and unknown fragments are probably marine in origin.

A single specimen of Dimeregramma marinum (Gregory) Ralfs was found in both samples. It is a littoral species rarely encountered on North European shores. According to Cleve Euler (1953), the same species, but under the name $D$. marina var. antigua A. Cleve, has probably been found as a Tertiary species in southern Lapland.

The silicoflagellates Dictyocha fibula, Distephanus speculum (Ehrenberg) Haeckel, D. speculum var. pentagonus Lemmerman and $D$. speculum var. septenarius (Ehrenberg) Joergensen are fairly common (16-19\% of the total diatom sum/sample). Silicoflagellates are also present in the Eemian interglacial sediments (e.g. Grönlund 1991).

The diatom taxa of the bottom part of the silty clay layer (samples from 0-20 cm) are almost the same as those in the upper part of the layer. Tabellaria flocculosa is again clearly dominant (84-92\%).

It is not easy to delineate the conditions under which the silty clay deposited from the results of the diatom investigation. T. flocculosa and other minor freshwater species are most likely part of the basic sedimentation, which probably occurred in a pool adjoining the ice front. Tabellaria flocculosa grew in the pool as a pioneering species. Its occurrence and preservation as colonies, and even as star-shaped colonies, is amazing. Sedimentation conditions must therefore have been tranquil and sedimentation rapid. Rapid sedimentation obviously contributed to the preservation of Tabellaria flocculosa as colonies. The saline water species in the middle of the layer are probably allochthonous, and may have been transported by a short influx from the environment, where there is an autochthonous or redeposited marine sediment. In all likelihood this material derived from deposits 
of the Eemian Baltic Sea in the immediate vicinity of Horonkylä (cf. Niemelä and Tynni 1979, Grönlund 1991).

\section{Correlation of diatom data}

Reworked and in situ saline or brackish Eemian Sea sediments, but no interstadial saline water deposits, have been found in Pohjanmaa (e.g. Niemelä \& Tynni 1979, Grönlund 1991). The diatom flora of the till-covered deposits at the Oulainen and Marjamurto sites north of Horonpää, which contain freshwater diatoms, is largerly similar to that at Horonpää (cf. Forsström 1982, Peltoniemi et al. 1989). One of the cores from Oulainen consists mostly of diatomite, which, according to the diatom flora, indicates neutral-alkaline water. Melosira (Aulacoseira) italica, Fragilaria and Pinnularia genera are dominant (Forsström 1982). The diatom content of diatomite lenses in the esker at Haapajärvi differs from that described from the Horonpää diatomite (cf. Aario 1966). Melosira (Aulacoseira) islandica, mainly as resting spores, is clearly dominant at Haapajärvi. The flora also contains a couple of diatom species indicating saline water. At Harrinkangas, the till matrix is rich in reworked saline diatoms and silicoflagellates, but the silt layer has only small amounts of freshwater diatoms (Gibbard et al. 1989).

There are some minor similarities between diatom floras presented earlier (Aario 1966, Forsström 1982, Gibbard et al. 1989, Peltoniemi et al. 1989 ) and that at Horonpää. Diatom stratigraphical correlation is, however, out of the question.

\section{CLASSIFICATION OF THE EARLY WEICHSELIAN INTERSTADIALS}

According to Forsström's classification (1988), interstadial sites with a high pine pollen content (e.g. Oulainen in Ostrobothnia) are correlated with the Brörup interstadial, and the birch-dominated sites in Peräpohjola (e.g. Kauvonkangas, Permantokoski and Kostonniska) with the Od- derade. The Horonpää sequence represent the Brörup type of interstadial. There are, however, no definitive proofs for this classification.

The difference between these two types may be due to the difference in latitude between Ostrobothnia and Peräpohjola, and hence both types may in fact represent the same interstadial, the Brörup (see also Donner 1983, 1990).

According to the pollen record from the European mainland, the north-south and also the westeast climate gradient was considerably steeper during the Early Weichselian interstadials than it is today (Behre 1989 and Zagwijn 1989). The combined effect of the general decline in temperature and the southward displacement of the Gulf Stream was also appreciably stonger than it is today (Behre 1989). In Scandinavia the cooler climate meant that glaciers were more extensive in the mountains than at present. The sea-level was lower than it is nowadays. The Baltic Sea had only a narrow connection with the oceans during the Brörup (Lundqvist 1992).

The increase in the continentality of the climate provoked by the more extensive glaciers, the lowering of sea-level and the southward displacement of the Gulf Stream undoubtedly affected the general pattern of vegetational zones. The pine forest zone may have had a totally different extension from that presented in Forsstöm's model based on data on present-day vegetation.

Further, if only part of an interstadial sediment is preserved, as may be the case at the Peräpohjola interstadial sites, correlation of remnant sequences with a certain Early Weichselian interstadials on the basis of biostratigraphy alone is uncertain.

Not one complete interstadial sequence has been recorded from central and northern Sweden. Therefore, correlation of the remnants of interstadial sediments with Finnish interstadial sites is difficult. The pollen record from sites in Sweden (Härnösand, Pilgimstad, Långsele) situated at approximately the same latitude as Horonpää reflects different vegetational phases from the Horonpää sequences. The vegetation of the Brörup interstadial in Central Sweden is characterized by a dominance of birch pollen and low pine pollen frequencies, indicating only distant pine forests. 
Spruce and larch probably grew as far north as Härnösand during a later phase of the interstadial (Ambrosiani 1990). All three interstadial sites were previously correlated with the Brörup, but recent investigations suggest that the sequence at Pilgrimstad may represent both the Brörup and the Odderade (Robertsson 1988, Robertsson and Ambrosiani 1992). Forsström (1988) also questions the age of Pilgrimstad and correlates it with the Odderade.

The model of the northern limit of pine forest during the Early Weichselian interstadials as proposed by Forsström (1988) has also been critized by Ambrosiani (1990). If the model is applied to the interstadial sites in Central and Northern Sweden, none of them can be correlated with the Brörup. However, if the limit of pine forest lay farther south on the Swedish side of the Baltic Sea, as suggested by Lundqvist (1978), correlation of these Swedish sites with the Finnish Brörup sites is reasonable (Ambrosiani 1990).

\section{SUMMARY}

The Horonpää site comprises two till units with intercalated sorted sediments and a diatomite layer. Even though ice flowing over the site caused folds and sand wedges in the diatomite layer the fossil record does not show any disturbances in the sequence studied. The diatomite layer is correlated with the Brörup interstadial; it contains a freshwater diatom flora and records the transition from an initial birch forest to a denser pine forest. Nenonen
(1995) correlates this layer with Lower-Weichselian ice free interval called the Horonkylä interstadial in isotope stage $5 \mathrm{c}$.

The silty clay layer overlying the lower till unit is interpreted as having been deposited close to the ice front. It contains only a few pollen grains and a very unusual diatom flora dominated almost exclusively by Tabellaria flocculosa. No conclusions can be drawn about vegetation cover from this layer. Sedimentation was probably rapid and tranquil. A disturbance in the sedimentation rate in the middle of the sequence is manifested in a greater number of pollen grains, a rise in the loss-on-ignition curve, and the presence of marine diatoms and silicoflagellates. This increase in abundance of organic material is interpreted as reflecting a brief influx of secondary material from eroded Eemian interglacial sediments.

ACKNOWLEDGEMENTS: We wish to express our sincere thanks to Prof. Raimo Kujansuu and $\mathrm{Dr}$ Keijo Nenonen for providing us with the material for this study and for valuable comments and useful discussions. We are thankful to anonymous reviewers for critical reading of the manuscript and valuable comments. Thanks are also due to Kristian Lindqvist for determination of the composition of siliceous sponge spicules, Eila Paavilainen for helping with laboratory work, Satu Moberg for drawing diagrams and figures, Jari Väätäinen for the photos and Gillian Häkli and Peter Sorjonen-Ward for correcting the English. 


\section{REFERENCES}

Aalto, M., Donner, J., Niemelä, J. \& Tynni, R. 1983. An eroded interglacial deposit at Vimpeli, South Bothnia, Finland. Geological Survey of Finland, Bulletin 324. 48 p.

Aalto, M., Donner, J., Hirvas, H. \& Niemelä, J. 1989. An interglacial beaver dam deposit at Vimpeli, Ostrobothnia, Finland. Geological Survey of Finland, Bulletin $348.34 \mathrm{p}$.

Aario, R. 1966. Kieselgur in fluvioglazialen Ablagerungen in Haapajärvi in Ostbottnien. Geological Survey of Finland, Bulletin 222, 3-30.

Ahti, T., Hämet-Ahti, L. \& Jalas, J. 1968. Vegetation zones and the sections in northwestern Europe. Annales Botanici Fennici 5, 169-211.

Ambrosiani, K.G. 1990. Pleistocene stratigraphy in Central and Northern Sweden. University of Stockholm, Department of Quaternary Research, Report 16, 1-15.

Ambrosiani, K.G. 1990. Interstadial minerogenic sediments at the Leveäniemi mine, Svappavaara, Swedish Lapland. In: Ambrosiani, K.G. Pleistocene stratigraphy in Central and Northern Sweden. University of Stockholm, Department of Quaternary Research, Report 16, 1-20.

Behre, K.-E. 1989. Biostratigraphy of the last glacial period in Europe. Quaternary Science Reviews 8, 25-44.

Cleve-Euler, A. 1953. Die diatomeen von Schweden und Finnland III. Kungliga svenska Vetenskapsakademiens handlingar 4. 5. (4) $232 \mathrm{p}$.

Donner, J. 1983. The identification of Eemian interglacial and Weichselian interstadial deposits in Finland. Annales Academiae Scientiarum Fennicae A III 136. 38 p.

Donner, J. 1988. The Eemian site of Norinkylä compared with other interglacial and interstadial sites in Ostrobothnia, western Finland. Annales Academiae Scientiarum Fennicae A III 149. 31 p.

Donner, J. 1990. The pollen analytical identification and definition of Quaternary interglacials and interstadials in Fennoscandia, with special reference to Finland. In S. Chanda (ed.) Current Perspectives in Palynological Research Silver Jubilee Commemoration Volume of the Journal of Palynology 1990-91, 139-150.

Diegerfelt, G. 1975. Post-glacial water level changes in Lake Växjön, central southern Sweden. Geologiska Föreningens i Stockholm Förhandlingar 97, 167-173.

Eriksson, B. 1993. The Eemian pollen stratigraphy and vegetational history of Ostrobothnia, Finland. Geological Survey of Finland, Bulletin 372.36 p.

Eriksson, B. \& Kujansuu, R. 1994. Late Pleistocene pollen flora with Larix from till-covered esker at
Hietamäki, Ostrobothnia, western Finland. Bulletin, Geological Society of Finland 66(2), 53-56.

Foged, N. 1958. The diatoms in the basalt area and adjoining areas of Archean rock in est Greenland. Meddelelser om Groenland 156, 4, $146 \mathrm{p}$.

Foged, N. 1964. Freshwater diatoms from Spitsbergen. Tromsö Museums Skrifter Vol. XI, 159 p.

Forsström, L. 1982. The Oulainen interglacial in Ostrobothnia, western Finland. Acta Universitatis Ouluensis Ser. A 136, Geologica 4. 123 p.

Forsström, L. 1988. The northern limit of pine forest in Finland during the Weichselian interstadials. Annales Academiae Scientiarum Fennicae. Ser A III 147. 24 p.

Gibbard, P., Forman, S., Salomaa, R., Alhonen, P., Jungner, H., Peglar, S., Suksi, J. \& Vuorinen, A. 1989. Late Pleistocene stratigraphy at Harrinkangas, Kauhajoki, western Finland. Annales Academiae Scientiarum Fennicae A III 150. 36 p.

Grönlund, T. 1986. Diatomite deposit in the basin Lake Soijärvi, central Finland. Bulletin Geological Society of Finland 58 (2), 53-45.

Grönlund, T. 1989. Holocene diatomites in central Finland, with special reference to Aulacoseira (Melosira) species. Geological Survey of Finland, Report of Investigation $87.34 \mathrm{p}$.

Grönlund, T. 1991. The diatom stratigraphy of the Eemian Baltic Sea on the basis of sediment discoveries in Ostrobothnia, Finland. Geological Survey of Finland, Report of Investigation 102. $26 \mathrm{p}$.

Hasle, G.R. \& Syvertsen E.E. 1990. Arctic diatoms in the Oslofjord and the Baltic Sea - a bio- and palaeogeographic problem. In: Simola H. (ed.) Proceedings of the Tenth International Diatom Symposium. Koenigstein: Koeltz Scientific Books, 285-300.

Haworth, E. Y. 1969. The diatoms of a sediment core from Blea Tarn, Langdale. Journal of Ecology 57, 429-39.

Hendey, N.I. 1964. An introductory account of the smaller algae of British coastal waters. Fishery Investigations IV Part V: Bacillariophyceae (Diatoms). Her Majesty's Stationery Office, London. 317 p.

Hirvas, H., Alfthan, A., Pulkkinen, E., Puranen, R. \& Tynni, R. 1977. Raportti malminetsintää palvelevasta maaperätutkimuksesta Pohjois-Suomessa vuosina 1972-1976. Summary: A report on glacial drift investigations for ore prospecting purposes in northern Finland 1972-1976. Geological Survey of Finland, Report of Investigation 19. $54 \mathrm{p}$.

Hirvas, H. \& Nenonen, K. 1987. The till stratigraphy of Finland. Geological Survey of Finland, Specian paper 3, 49-63. 
Iisalo, E. 1992. Observations on the stratigraphy of Weichselian tills and subtill eskers in central Ostrobothnia, Finland. Geological Survey of Finland, Report of investigations $112.42 \mathrm{p}$.

Iisalo, E. 1996. Onko Ylivieskan Mertuanojan harju Veiksel-interstadiaalinen? Geologi 48(3), 58-63.

Iisalo, E., Kurkinen, I. \& Niemelä J. 1974. Moreenipeitteisiä harjuja Pohjanmaalla. Summary: Till-covered eskers in Ostrobothnia. Geologi 26 (5-6), 51-52.

Ilvonen, E. 1973. Eem-kerrostuma Savukosken Soklilla. Summary: An Eem-interglacial deposit at Sokli in Savukoski, Finnish Lapland. Geologi 25, 81-83.

Jokinen, S., Grönlund, T., Kuivasaari, T. \& Nenonen, K. 1993. Virtasalmen Heponiemen moreeninalainen liejukerrostuma. Geologi 45. 3, 82-87.

Knudson, B. 1952 The diatom genus Tabellaria I. Taxonomy and morfology. Annales of botany, N.S. Vol. XVI, 69, 421-440.

Kujansuu, R., Saarnisto, M., Räisänen, M-L \& Hansel A.K. 1991. Fossil soil of Kärjenkoski and its correlatives in Ostrobothnia, western Finland. Geological Survey of Finland, Special Paper 12, 119-126.

Kurkinen, I. 1973. Soravarojen inventointi TVL:n Vaasan piirissä. Geologinen tutkimuslaitos, Osaraportti I. 79 p.

Lundqvist, J. 1978. New information about Early- and Middle Weichselian interstadials in northern Sweden. Sveriges Geologiska Undersökning C 752. 31 p.

Lundqvist, J. 1992. Glacial stratigraphy in Sweden. Geological Survey of Finland, Special Paper 15, 43-59.

Miller, U. 1971. Diatom floras in the interglacial sediments at Leveäniemi. In Lundqvist, J. (ed.) The interglacial deposit at the Leveäniemi mine, Svappavaara, Swedish Lapland. Appendix 5. Sveriges geologiska undersökning C 658, 104-163.

Nenonen, K. Pleistocene stratigraphy and reference sections in southern and western Finland. Kuopio: Geological Survey of Finland, Regional office for MidFinland. 205 p.

Niemelä, Jouko 1978. Etelä-Pohjanmaan sora- ja hiekkamuodostumien geologinen tausta. Rakennusgeologinen yhdistys - Byggnadsgeologiska föreningen r.y:n julkaisuja - Papers of the Engineering - Geological Society of Finland 12 (91). 15 p.

Niemelä, Jouko (ed.) 1979. Suomen sora- ja hiekkavarojen arviointiprojekti 1971-78. Summary: The gravel and sand resources of Finland; an inventory project 1971-78. Geologinen tutkimuslaitos, Tutkimusraportti 42. $119 \mathrm{p}$.

Niemelä, J. \& Tynni R. 1975. Alustava tiedonanto EteläPohjanmaan moreeninalaisten harjujen iästä. Summary: A preliminary report on the age of the sub- morainic eskers in Southern Ostrobothnia. Geologi $27,15-16$.

Niemelä, J. \& Tynni, R. 1979. Interglacial and interstadial sediments in the Pohjanmaa region, Finland. Geological Survey of Finland, Bulletin 302. 48 p.

Nieminen, K. 1976. Diatomite deposits in Finnish bogs. Proceedings of the 5th International Peat Congress. New Recognitions of Peatlands and Peat 2. Poznan, Polan, 123-128.

Patrick, R. \& Reimer, C.W. 1966. The diatoms of the United States, exclusive of Alaska and Hawaii. 1, Monographs of The Academy of Natural Sciences of Philadelphia, 13. 688 p.

Peltoniemi, H., Eriksson, B., Grönlund, T. and Saarnisto M. 1989. Marjamurto, an interstadial site in a till-covered esker area of central Ostrobothnia, western Finland. Bulletin of Geological Society of Finland 61 part 2, 209-235.

Punkari, M. 1978. Skandinavian jäätikön deglasiaatiovaiheen kielekevirrat Etelä-Suomessa. Summary: The ice lobes of the Scandinavian ice sheet during the deglaciation in South Finland. Geologi 31 (2), 22-28.

Renberg, I. 1976. Paleolimnological investigations in lake Prästsjön. I: Engelmark, R., Olsson, I.U., Renberg, I. \& Zackrisson, O. (eds) Palaeo-ecological investigations in coastal Västerbotten N. Sweden. Preprint from Early Norrland 9. 113-159.

Renberg, I. 1978. Paleolimnolog and varve counts of the annually laminated sediment of Lake Rudetjäm, Northem Sweden. In: Archaeological and palaeoecological studies in Medelpad, N. Sweden. Reprint from Early Norrland 11, 63-91.

Robertsson, A.-M. 1988. Reinvestigations of the biostratigraphy of the till-covered sediments at Pilgrimstad and Öje, Central Sweden, Paper 2. In: Robertsson, A.-M. Biostratigraphical studies of interglacial and interstadial deposits in Sweden. University of Stockholm. Department of Quaternary Research Report 10.53 p.

Robertsson, A.-M. \& Ambrosiani, K. 1992. The Pleistocene in Sweden - a review of research, 1960-1990. Sveriges Geologiska Undersökning, Ser. Ca 81, 229306.

Round, F.E., Crawford, R. M. \& Mann, D.G. 1990. The diatoms - Biology and morphology of the genera. Cambridge: Cambridge University Press. $747 \mathrm{p}$.

Tynni. R. 1982. The reflection of geological evolution in Tertiary and interglacial diatoms and silico-flagellates in Finnish Lapland. Geological Survey of Finland, Bulletin 320. 40 p.

Zagwijn, W.H. 1989. Vegetation and climate during warmer intervals in the Late Pleistocene of western and central Europe. Quaternary International 3/4, 57-67. 


\section{Plate 1.}

Figs 1-4. Tabellaria flocculosa, LM. Scale bar $=10 \mu \mathrm{m}$.

Fig. 1. Frustule in girdle view, Fig. 2. Star-shaped colony morphology, Fig. 3. Frustule in valve view, 4. Zigzag colony.

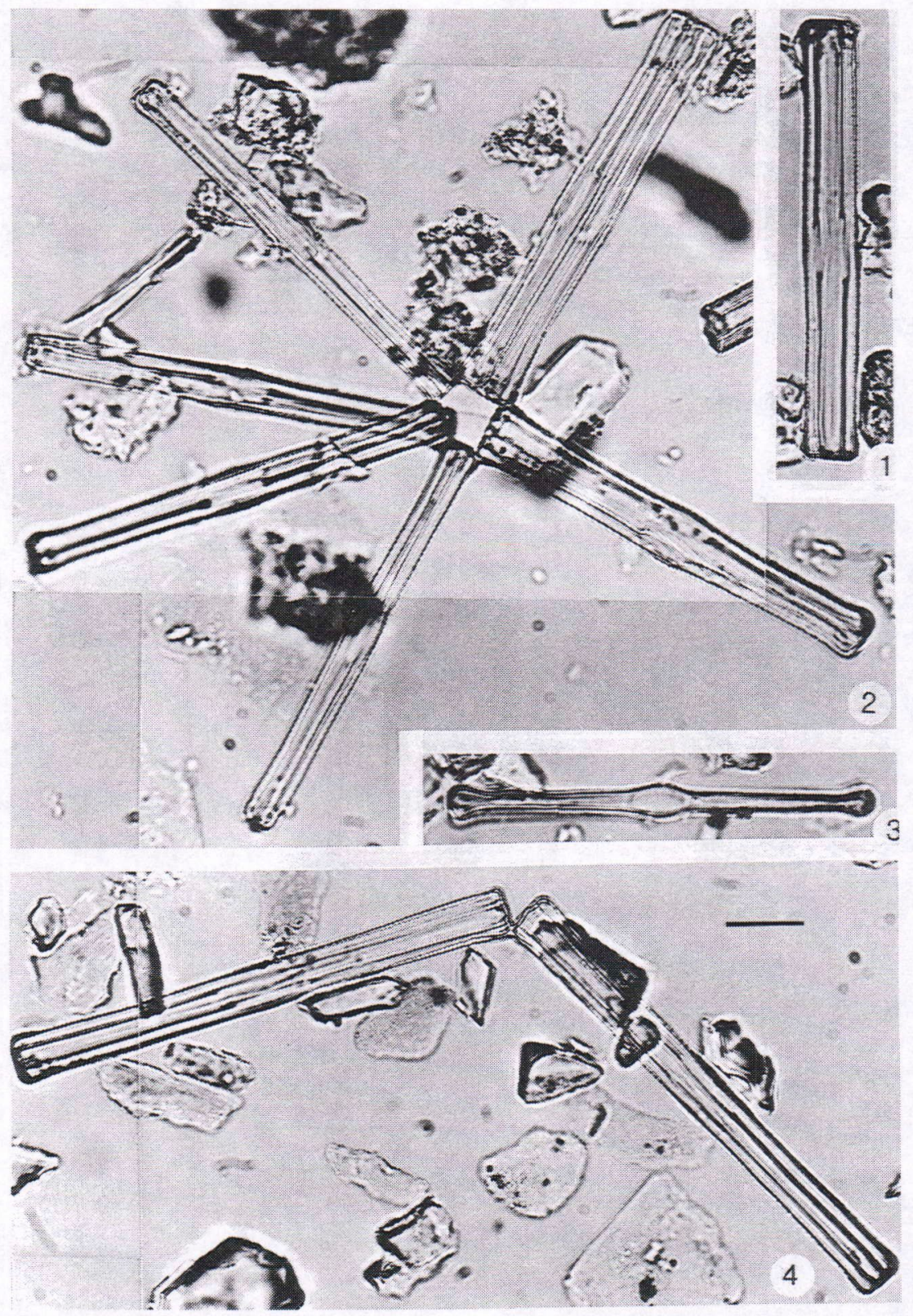


Plate 2.

Diatoms from the silty clay layer, LM. Scale bar $=10 \mu \mathrm{m}$.

Fig. 1. Chaetoceros mitra. Fig. 2. Podosira montagnei. Figs 3-4. Corroded Navicula species. Fig. 5. Dictyocha fibula. Fig. 6. Distephanus speculum var. septenarius.
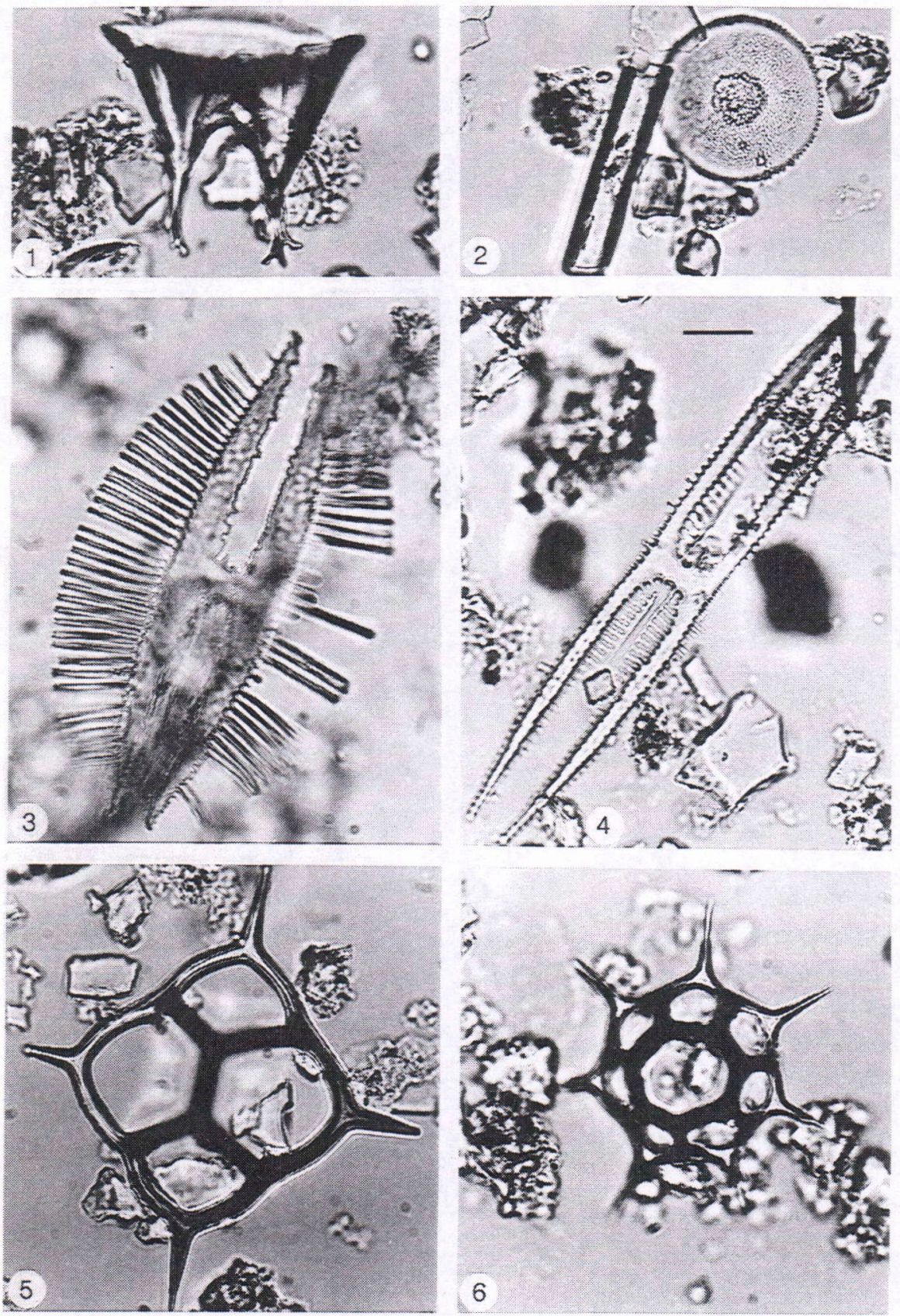